مستحضرات التجميل والأدوية من ألبان البهائم ( دراسـة فقهية )

\author{
خالد بن عبد الرحمن العسكر \\ الأستاذ المشارك بكلية التربية- جامعة الأمير سطام بن عبد العزيز - المملكة العربية السعودية العسكر بادية
}

Kalid1927@hotmail.com

DOI: https://doi.org/DOI:10.31559/sis2020.4.1.3

\title{
الملخصص :
}

اتجهت العديد من الشركات المُصنّعة لمواد التجميل والعناية بالبشرة تضمين اللبن أو الحليب في العديد من منتجاتها وجعله

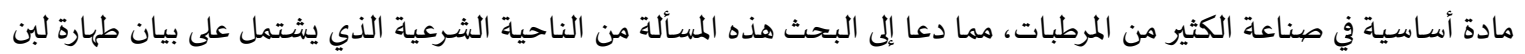

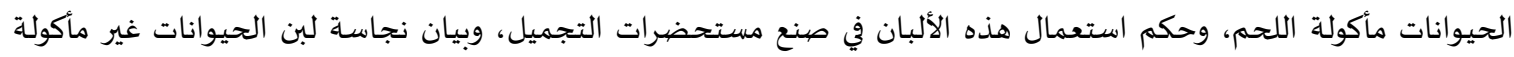

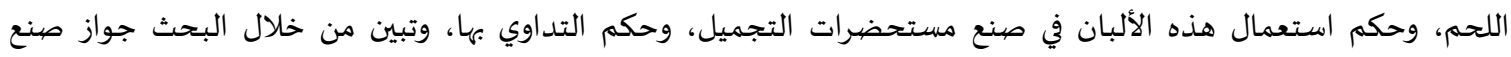

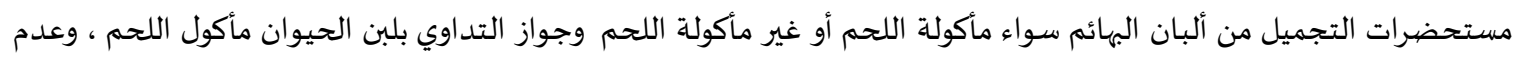

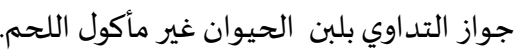

الكلمات المفتاحية: مستحضرات؛ تجميل؛ الأدوية؛ الألبان؛ الهائم.

إن الحمد الله نحمده ونستعينه ونستغفره ونتوب إليه ونعوذ بالله من شرور أنفسنا وسيئات أعمالنا، من يهده الله فلا مضل لها،

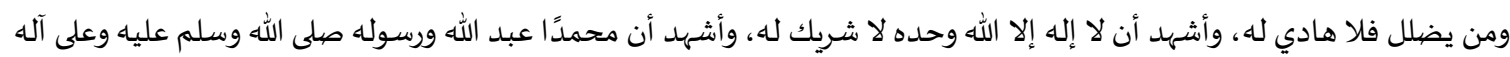

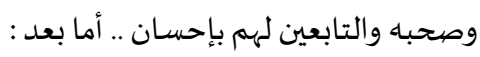
يعد الحليب من أهم المواد التي تدخل في تركيب مستحضرات التجميل وتنظيف البشرة، وذلك لأن الحليب له أثر في تجدئ تجديد

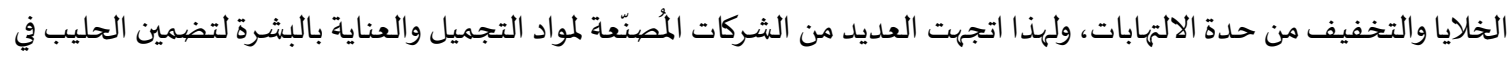

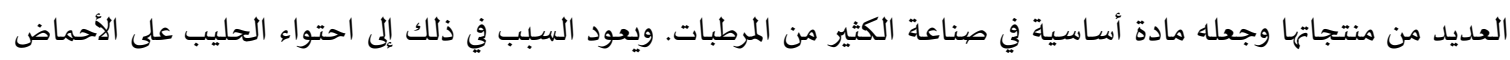

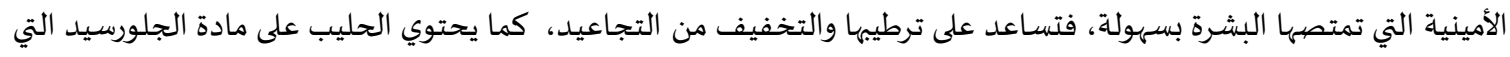

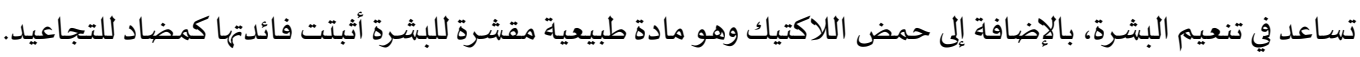

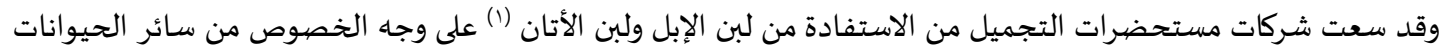

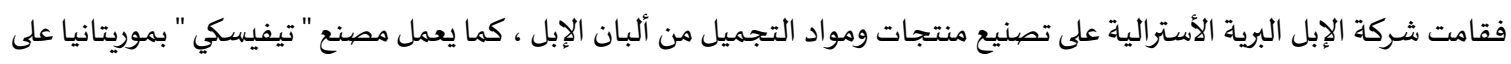

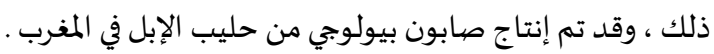

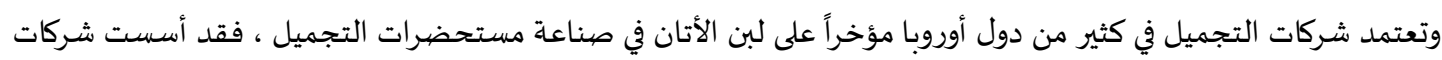

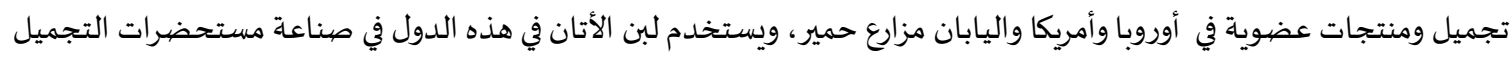

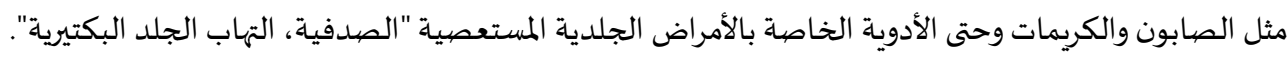

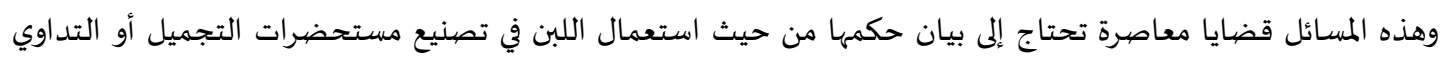

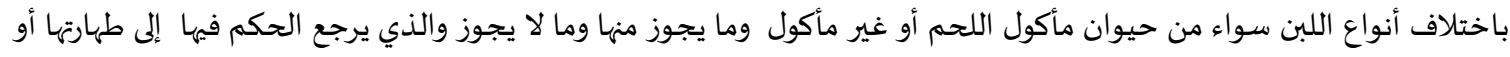

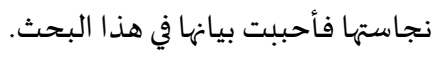


مشكلة البحث :

يوجد في هذا العصر بعض مستحضرات التجميل التي صنعت من ألبان البهائم، وهذه المسألة تحتاج إلى بيان الحكم الشرعي

في تصنيعها واستخد امها .

وتبرزمشكلة البحث من خلال التساؤلات التالية :

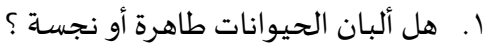

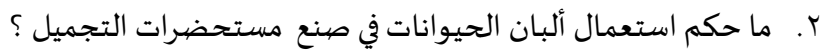

r. ما حكم استعمال ألبان الحيوانات في صنع الأدوية ؟

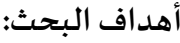

ا ـ بيان طهارة أو نجاسة ألبان الحيوانات

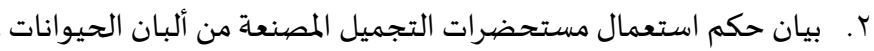

r. بيان حكم التداوي بألبان الحيوانات.

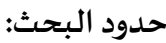

بيان حكم التداوي أو استعمال مستحضرات التجميل المصنعة من ألبان الحيوانات، وما ذكره علماء المذاهب الأربعة من مسائل تقاس عليها هذه المسألة .

منهج البتحث:

المنهج الذي سرت عليه في البحث المنهج الاستقرائي الاستنتاجي، وذلك باستقراء المادة العلمية للموضيوع من المصادر الأصلية

لكتب الفقه عامة وكتب فقه المذاهب الأربعة خاصةة مع مراجعة ما كتباه المعاصرون في هذا الموضوع.

إجراءات البحث:

1. إذا كانت المسألة من مواضع الاتفاق فأذكر حكمها بدليله مع توثيق الاتفاق من مظانه المعتبرة.

r. إذا كانت المسألة من مسائل الخلاف، فاتبعت ما يأتي:

حررت محل الخلاف في المسائل التي بعض صورها محل اتفاق وبعضها محل خلاف.

ذكرت الأقوال في المسألة ومن قال بها من الأئمة الأربعة مع ذكر الأدلة لكل قول .

r. قمت بتوثيق الأقوال الفقهية من كتب المذاهب الأربعة مرتبة حسب أقدمية المذاهب: الحنفية، فالمالكية، فالشافعية،

فالحنابلة.

$$
\text { ع. عزوت الآيات القرآنية بذكر اسم السورة ورقم الآية، مع كتابتها بالرسم العثماني. }
$$

0. قمت بتخريج الأحاديث والآثار، فإن كان الحديث في الصحيحين أو في أحدهما اكتفيت حينئذ بتخريجاه منهما، وإن كان في غيرهما

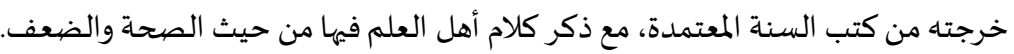

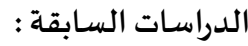

هذه المسألة من المسائل المعاصرة التي لم أجد فيها بحثاً في صنع مستحضرات التجميل ، وإنما يوجد بحوث في التداوي ومن ذلك :

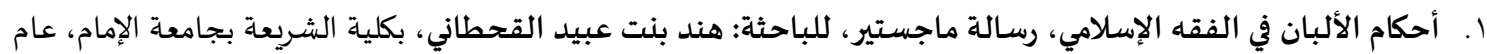

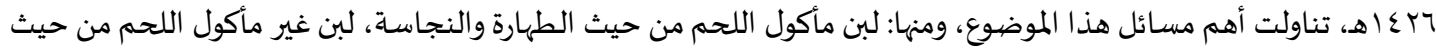

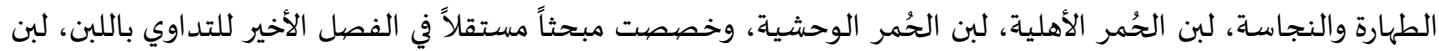
الحيوان المباح، ولبن الحيوان المحرم، وهذه المسائل هي محور ومرتكز موضهوع الباحث.

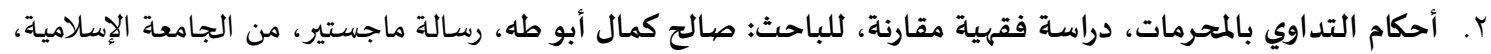

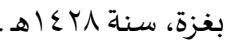
r. الأحكام الفقهية المتعلقة بمعاطن الإبل والتداوي بألبانها وأبوالها، مع ذكر ما توصل إليه الطب الحديث، للدكتور: مرضي ناصر آل إدريس، بحث محكم ومنشور في مجلة جامعة طيبة للآداب والعلوم الإنسانية، سنة بسع اهـ الهـ 
فهذه البحوث بحثت مسألة التداوي وأما هذا البحث فإنها في حكم صنح المستحضرات التجميلية من ألبان البهائم ، وأضفت مسألة التداوي تتمة للفائدة.

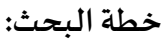

قسمت البحث إلى مقدمة وتمهيد ومبحثين وخاتمة : المقدمة وتشتمل على أهمية البحث ومشكلة البحث أهدافه وحدودده ومنهجاه وإجراءاته والدراسات السابقة وخطته

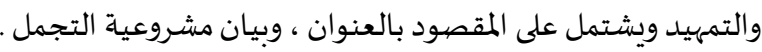

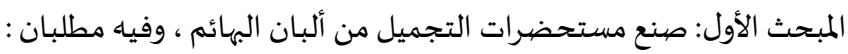

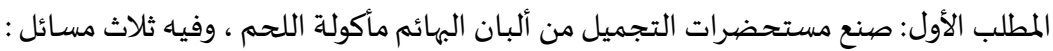

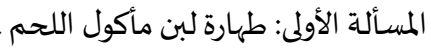

المسألة الثانية: حكم استعمال مواد مصنعة من الأطعمة في التنظيف.

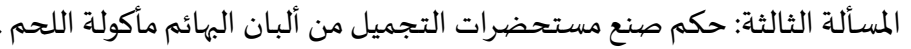

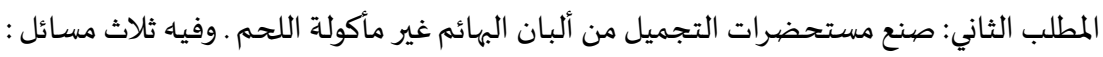

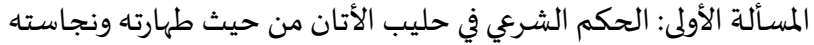

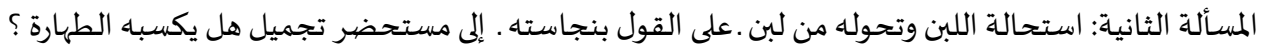

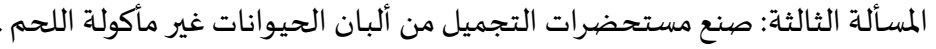

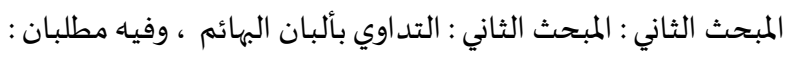
المطلب الأول : حكم التداوي بألبان الإبل . المان.

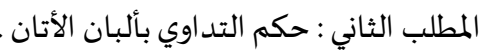
والخاتمة وتشتمل على أهم نتائج البحث . والله أعلم ، وصلى الله وسلم على نبينا محمد وآله وصحبه أجمعين البحثل التمهيد يشتمل هذا التمهيد على بيان المقصود من العنوان وبيان مشروعية التجمل .

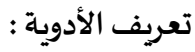

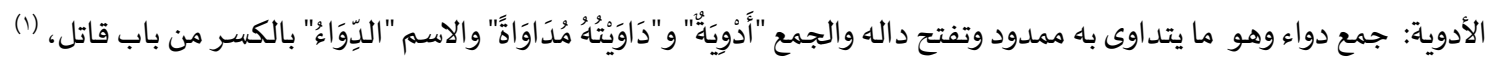

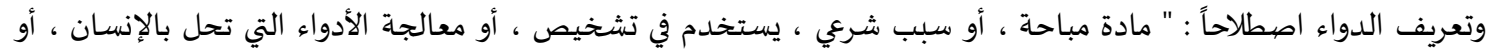

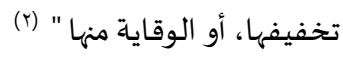
تعريف مستحضرات التجميل:

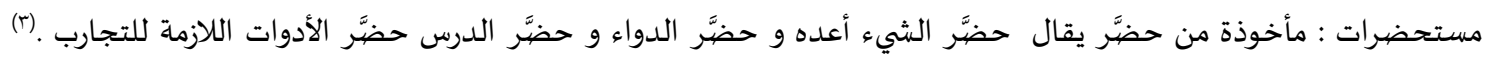

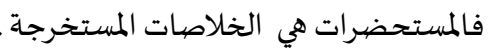

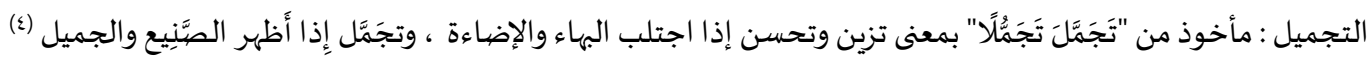

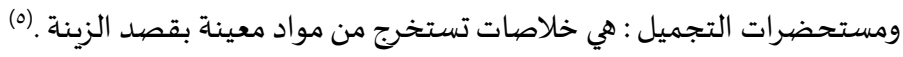

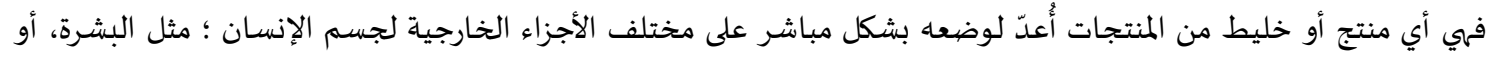

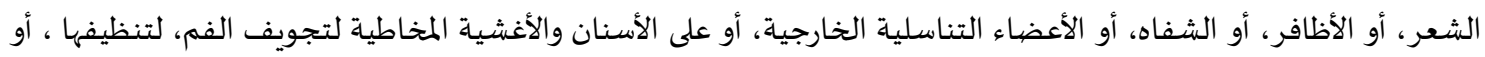

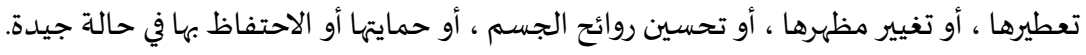

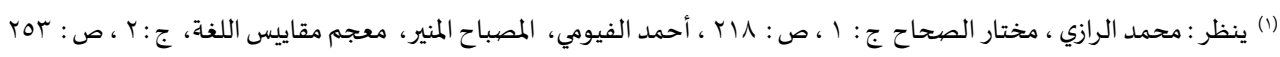

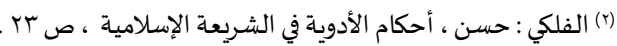

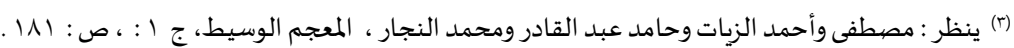

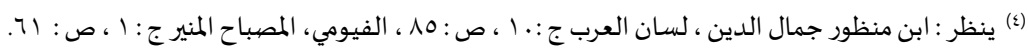

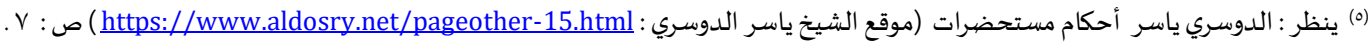


الههائم : جمع بهيمة وهي كل ذات أربع من دواب البر والبحر، وكل حيوان لا يميز فهو بهيمة ، والجمع " بهائم "(()

مشروعية التجمل:

إن دين الإسلام يحث على الجمال لما جاء في الحديث (إن الرجل يحب أن يكون ثوبه حسناً ونعله حسناً فقال عليه الصهاة

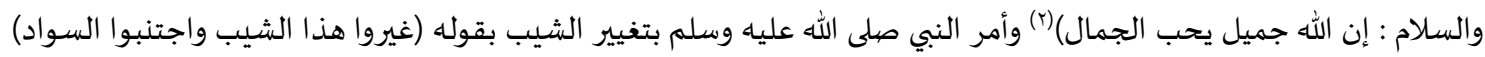

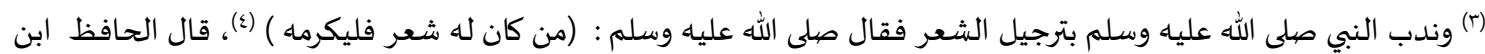

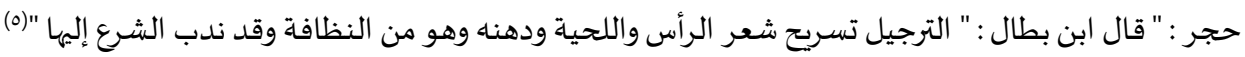

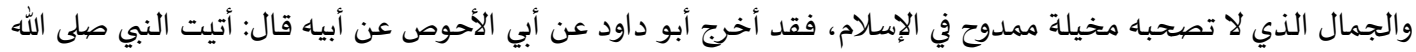

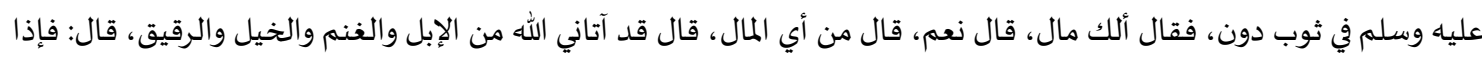

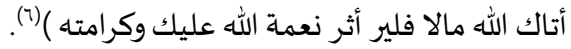
قال المناوي في فيض القدير: " وذلك بأن يلبس ثيابا تليق بحاله نفاسة وصفاقة ونظافة ليعرفه المحتاجون للطلب مناه، مع (v) " رعاية القصيد وتجنب الإسراف...

\section{المبحث الأول : صنع مستحضرات التجميل من ألبان الههائم}

اللبن إما أن يكون من حيوان مأكول اللحم أو من غير مأكول اللحم، ولذا أبين في هذا المبحث بيان حكم استخدام ألبان

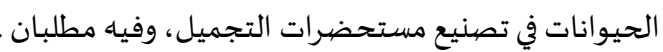

المطلب الأول : صنع مستحضرات التجميل من ألبان البهائم مأكولة اللحم ، وفيه ثلاث مسائل .

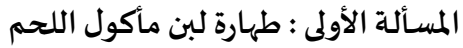

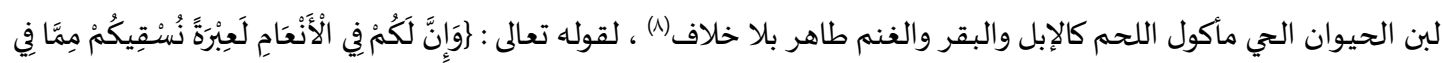

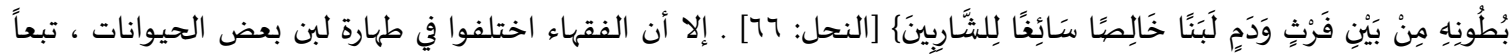

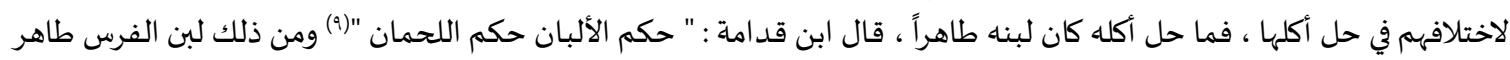

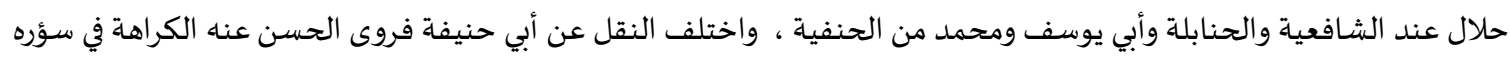

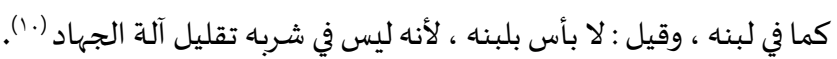

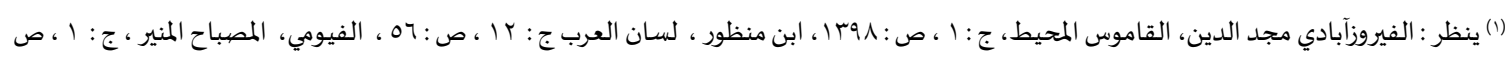

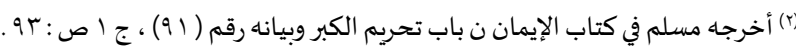

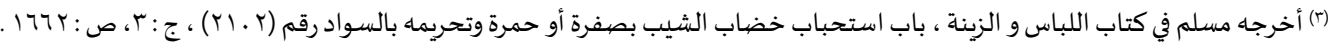

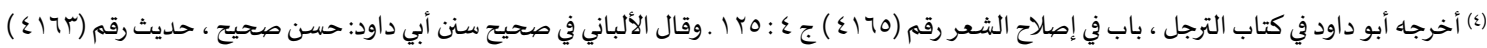

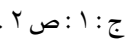

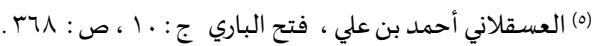

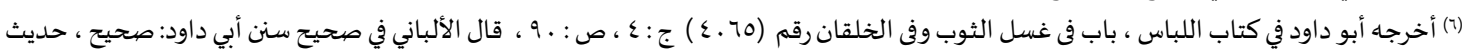

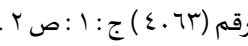

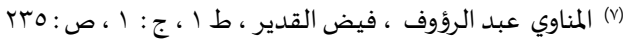

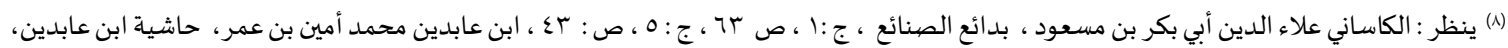

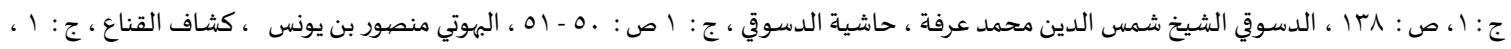

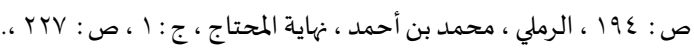

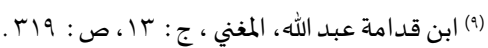

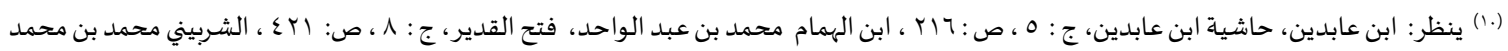

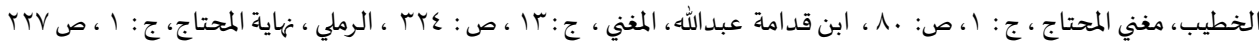


ولبن الفرس نجس عند المالكية بناء على تبعية اللبن للحم، فقد قالوا : لبن غير الآدمي تابع للحماء في الطهارة بعد التذكية فإن كان

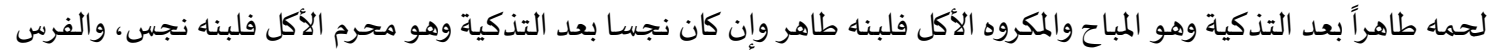

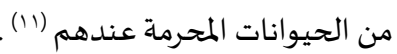
المسألة الثانية: حكم استعمال مواد مصنعة من الأطعمة في التنظيف

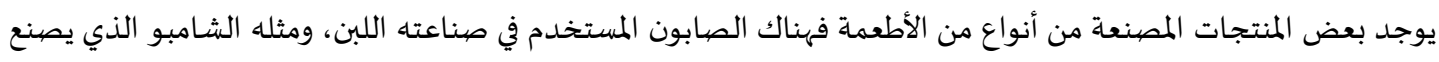

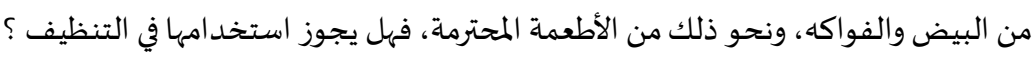
اختلف العلماء في ذلك على قولين :

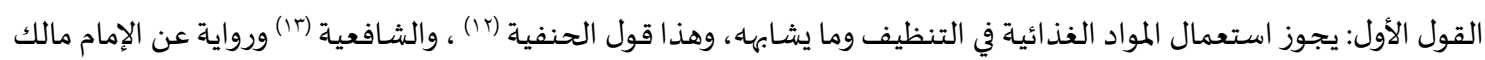

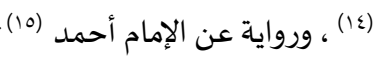
جاء في الفتاوى الهندية : "وفي نوادر هشام رحماه الله تعالى سألت محمداً رحماه الله تعالى عن غسل اليدين بالدقيق والسويق بعد

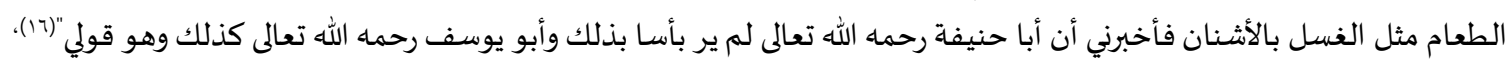

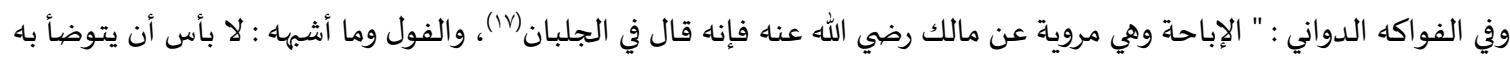

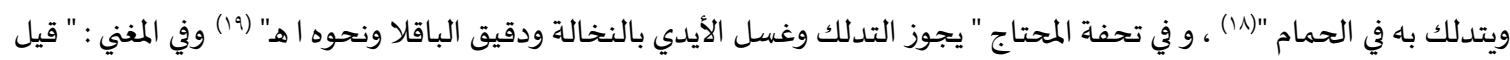

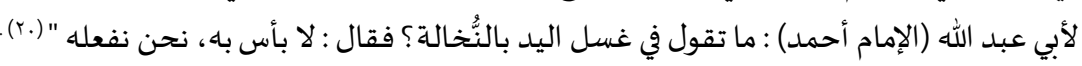

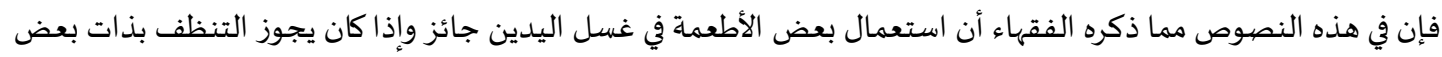

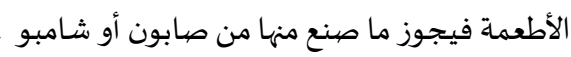
القول الثاني: أنه يكره استعمال الطعام في التنظيف، وهذا القول هو هابون المعتمد عند المالكية (Ir) وهو قول الحنابلة، إلا أن الحنابلة خصوا الكراهة بما يقتات من الطعام (rr) . قال في حاشية العدوي: " وكره غسل اليد بشيء من الطعام كدقيق الحنطة أو بشيء من دقيق القطاني كراهة تنزياه وقيل كراهة

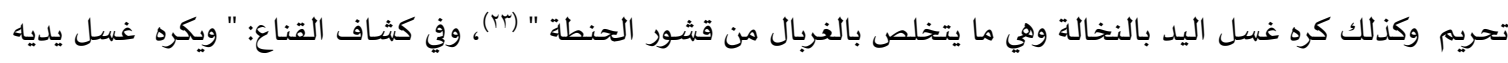
بطعام وهو القوت ولو بدقيق حمص وعدس وباقلاء ونحوه، قال الشيخ : الملح ليس بقوت وإنما يصلح باه القوت فعليه لا يكره الغسل

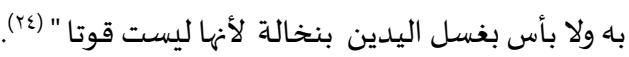
فالقول المشهور عند المالكية هو القول بالكراهة بلا تخصيص نوع عن نوع بينما نجد أن الحنابلة بلابلة خصيوا الكراهة بما كان قوتاً.

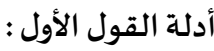

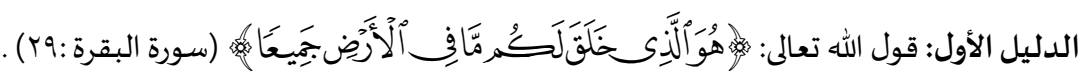

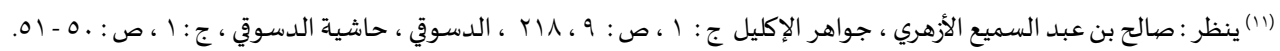

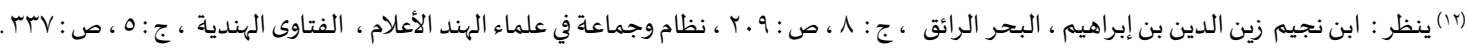

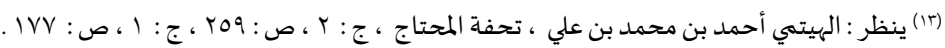

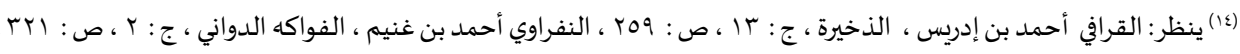

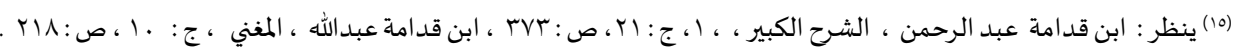

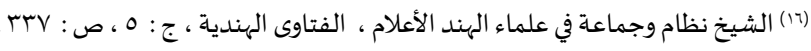

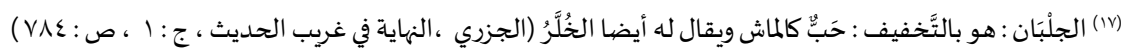

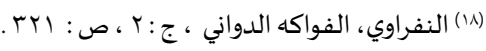

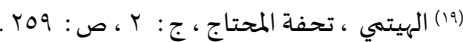

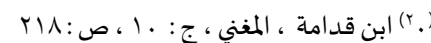

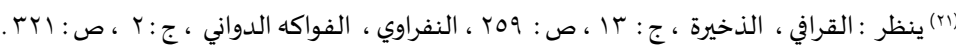

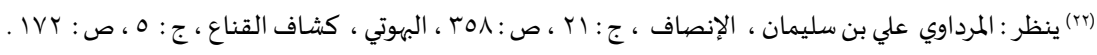

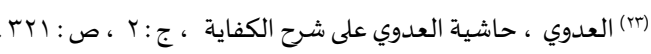

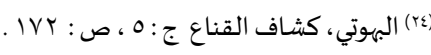


قال الشوكاني:" اعلم أن الأصل في كل شيء أنه يجوز للمالك أن يتصرف فيه بما شاء من أنواع التصرفات كما يفيده قوله عز وجل:

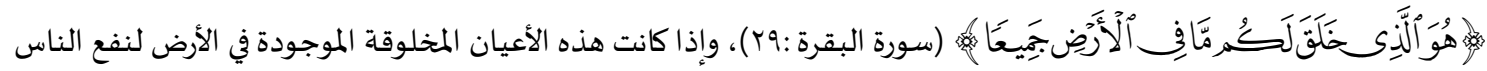

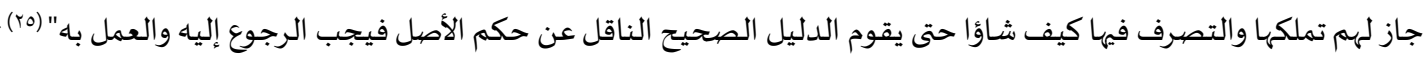

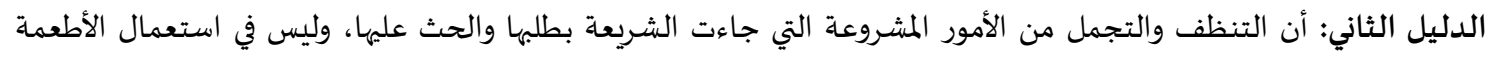

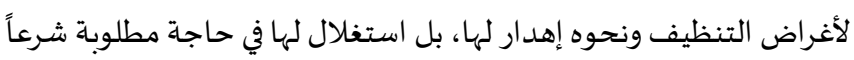

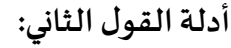

الدليل الأول: أن ذلك يفضي إلى خلطها بالأدناس والأنجاس فنهي عنه كما ينهى عن إزالة النجاسة بها (r) .

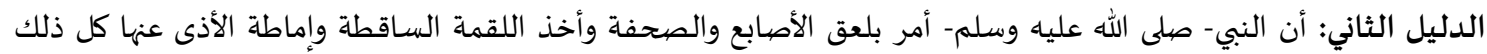

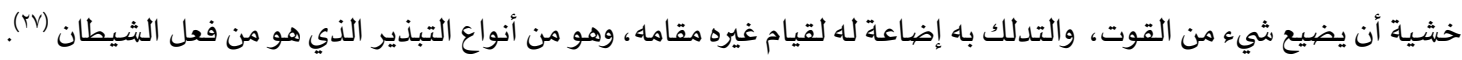
الترجيح:

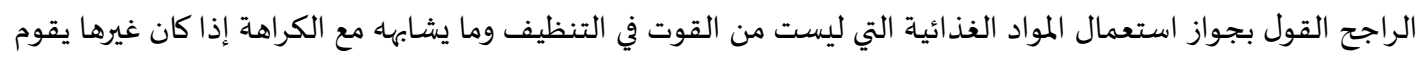

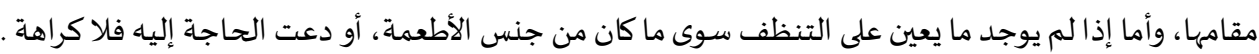

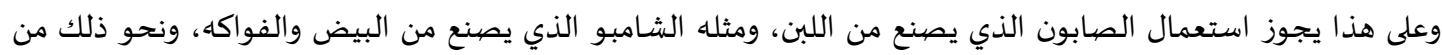

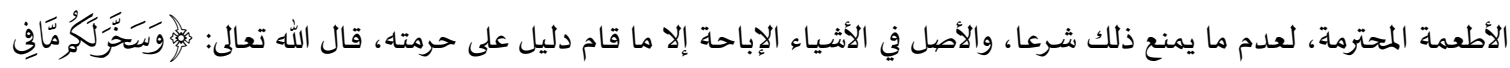

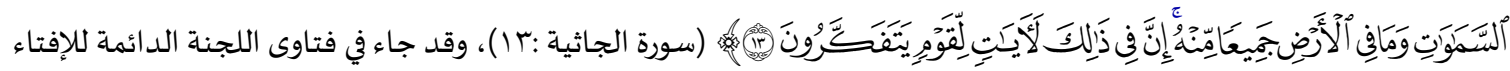

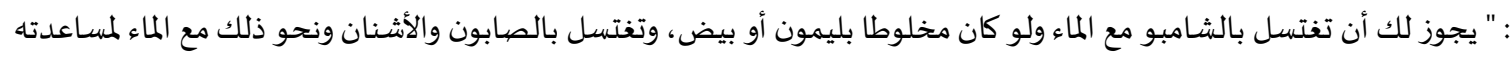

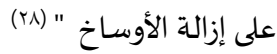

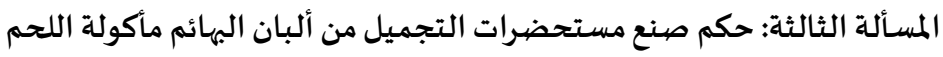

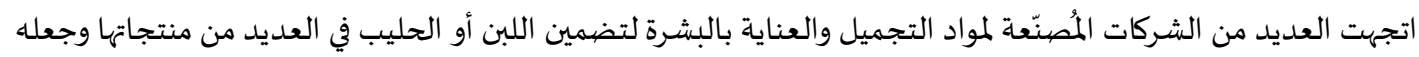

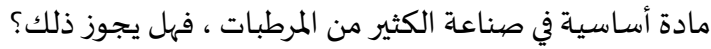

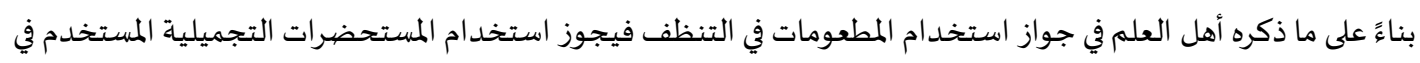
صناعتها ألبان الحيوانات مأكولة اللحم ويدل على ذلك الك الأدلة الألة الآتية :

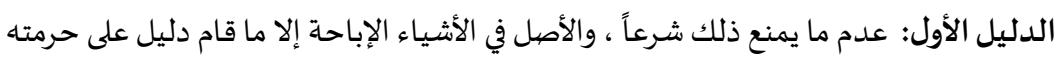

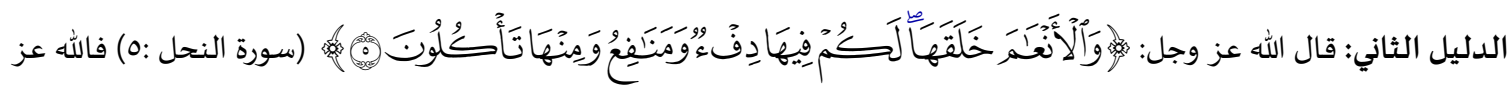

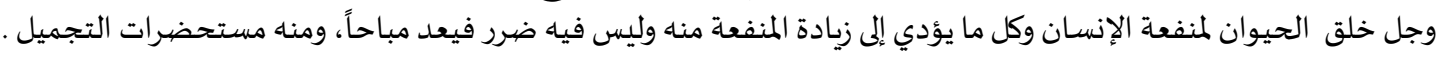

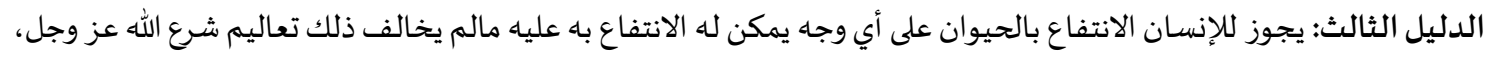

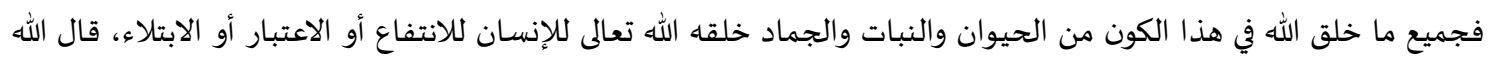

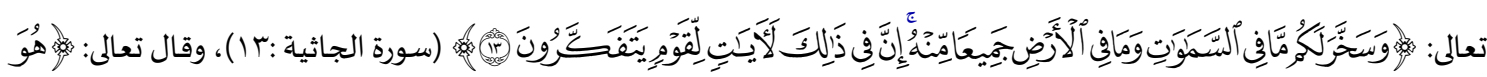

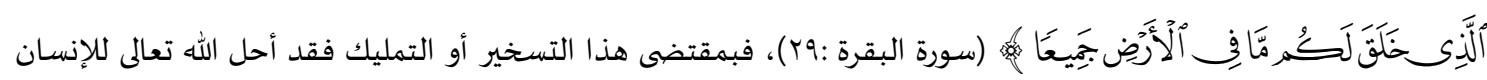

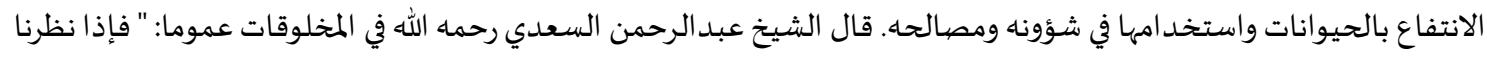

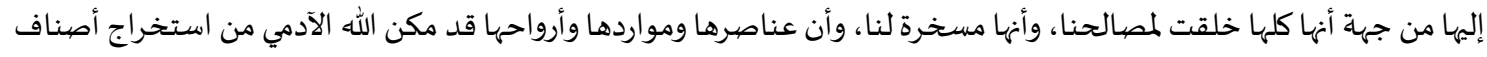

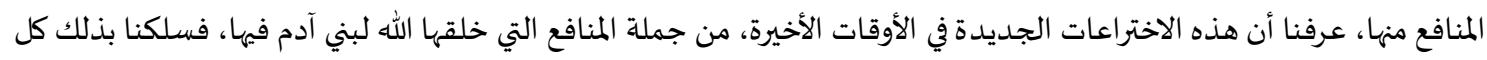

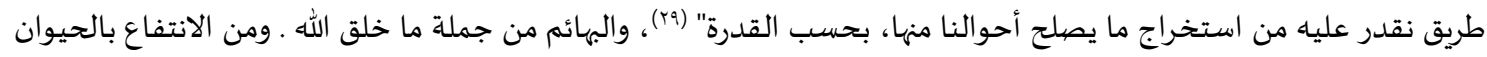

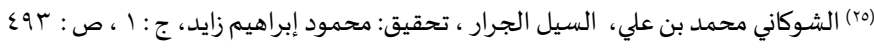

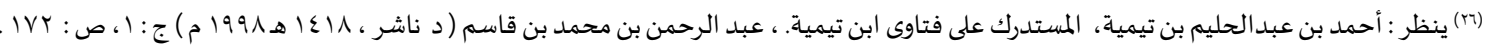
(TV)

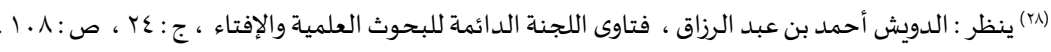

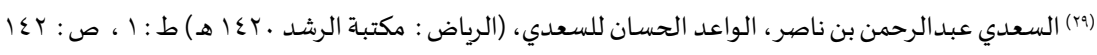


صنع الجيلاتين (.r) من أجزاء الحيوان وهي مادة التي تستخدم في الكريمات والأطعمة وبعض الأدوية وقد صهدر قرار مجلس المجمع

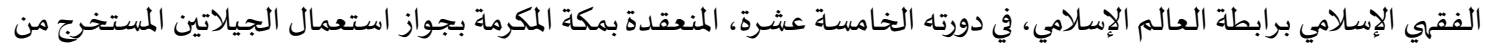

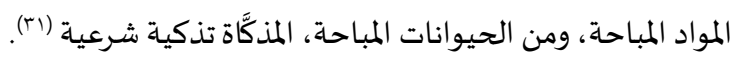
فالكريمات والجل التي تنتج من مادة الجيلاتين الحيواني التي أخذت من حيوان مأكول اللحمم مذكى ذكاة شرعية فهي طاهرة ويجوز

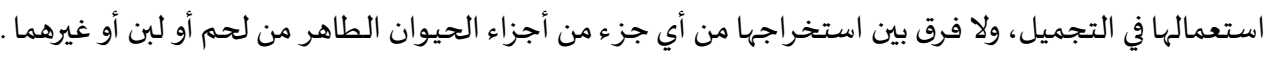

المطلب الثاني: صنع مستحضرات التجميل من البان البهائم غير مأكولة اللحم: وفيه مسألتان

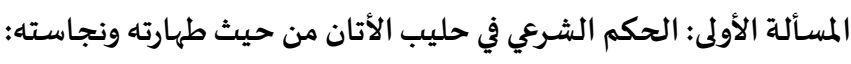
اختلف العلماء في هذه المسألة على قولين:

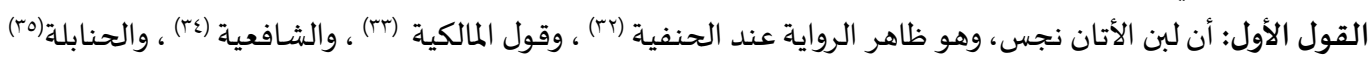

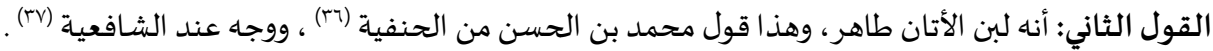

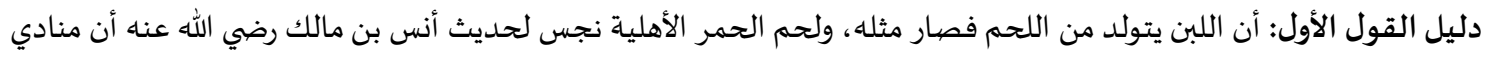

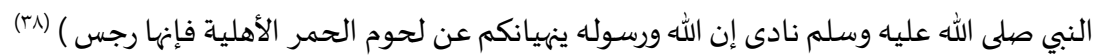
دليل القول الثاني: القياس على عرق الحمار فإنه طاهر عندهم فكذلك لبناه ، لأن كلا منهما متولد مناه (ra). الترجيح: الراجح القول الأول بنجاسة لبن الأتان وأما قياس لبن الأتان على عرق الحمار فيه نظر؛ لأنه قياس على مسألة مختلف فيها والخلاف فيها كالخلاف في اللبن

المسألة الثانية: استحالة اللبن وتحوله من لبن على القول بنجاسته إلى مستحضبرتجميل هل يكسبه الطهارة ؟ هذه المسألة يبحثها الفقهاء في النجاسة العينية إذا استحالت هل تطهر ، وقبل بيان حكم المسألة اذكر تعريف الاستحالة:

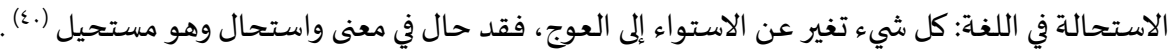

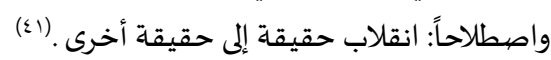

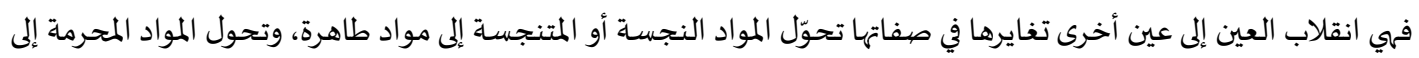

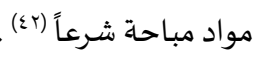
مسألة استحالة العين النجسـة هل تكسبها الطهورية ؟ موادي اتفق الفقهاء على طهارة الخمر إذا صارت خلا بنفسها من غير فعل فاعل. أما غير الخمر من النجاسـات فهو محل خلاف بينها في طهارتها بالاستحالة على قولين:

(r.) الجيلاتين : مادة شبه زلالية لينة لزجة غير قابلة للذوبان في الماء تستخرج من عظام الحيوان وأنسجته بإغلائه الطويل في الماء ( انظر : المعجم الوسيط ج ا

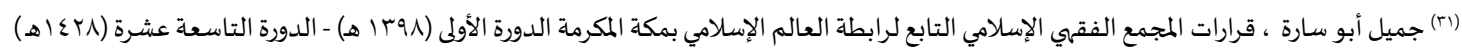

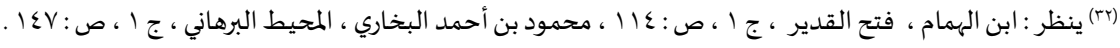

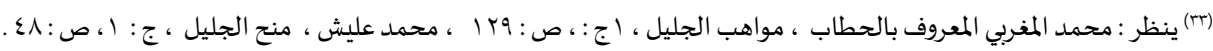

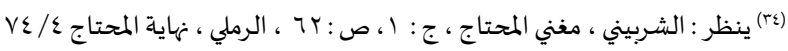
)

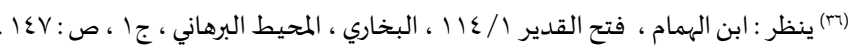

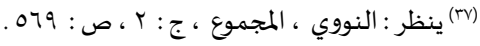

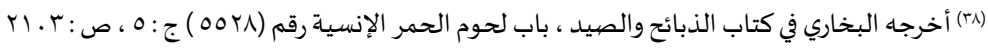

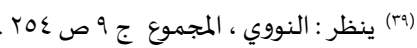

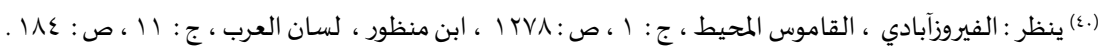

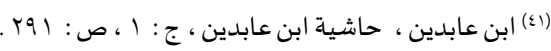

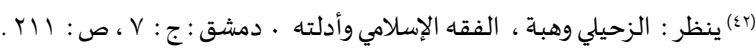


القول الأول: أن استحالة النجاسة إلى حقيقة أخرى تكسبه الطهارة ، وهذا قول أبي حنيفة ومحمد بن الحسن (rاء)، والمالكية وقيدوا

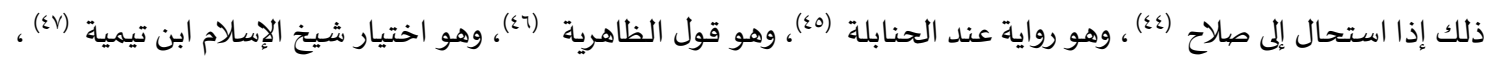

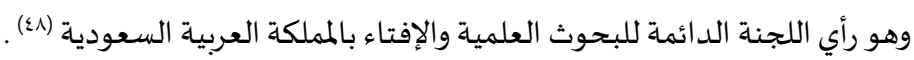
القول الثاني: أن استحالة النجس وزوال أعراض النجاسة عنده وتبدلها بأوصاف طيبة لا تصيره طاهراً إلا الخمر إذا تخللت بنفسها، التهاء

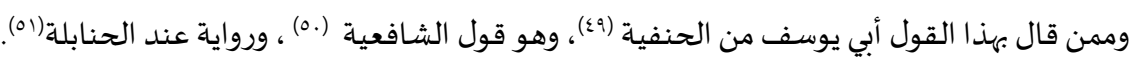
أدلة القول الأول :

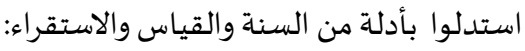

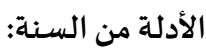

ا. حديث أبي سعيد الخدري رضي الله عنها أن رسول الله صلى الله عليه و سلم قال : ( والمسك أطيب الطيب )(ro).

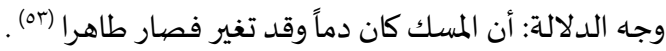

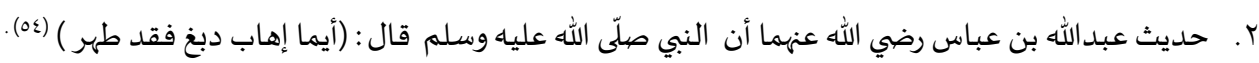

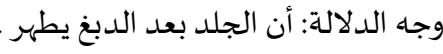
الدليل من القياس:

القياس على الخمرة إذا انقلبت خلاً، وجلود الميتة إذا دبغت والجلالة إذا حبست. (00) قال ابن القيم: " فالقياس الصحيح: تعدية ذلك إلى سـائر النجاسات إذا استحالت، وقد" نبش النبي صلى الله عليه وسلم قبور

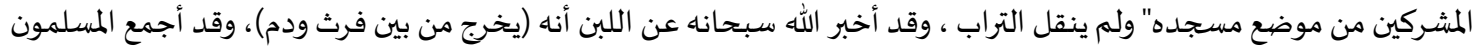

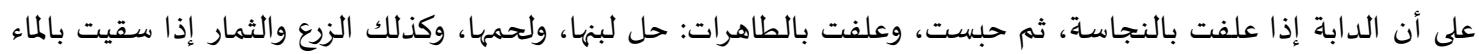
النجس، ثم سقيت بالطاهر: حلت؛ لاستحالة وصف الخبث، وتبدله بالطيب، وعكس هذا أن الطيب إذا استحال خبيثا: صار

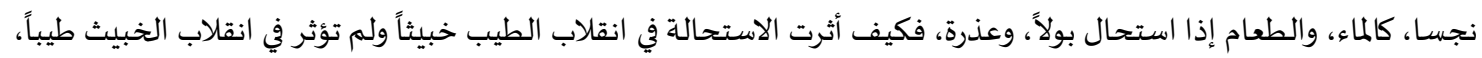

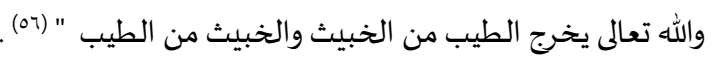

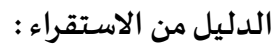

قال شيخ الإسلام ابن تيمية: " الاستقراء دلنا أن كل ما بدأ الله بتحويله وتبديله من جنس إلى جنس مثل جعل الخمر خلاً

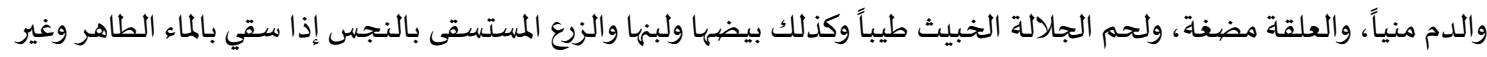
ذلك فإنه يزول حكم التنجس ويزول حقيقة النجس واسماه التابع للحقيقة ، وهذا ضروري لا يمكن المنازعة فياه، فإن جميع

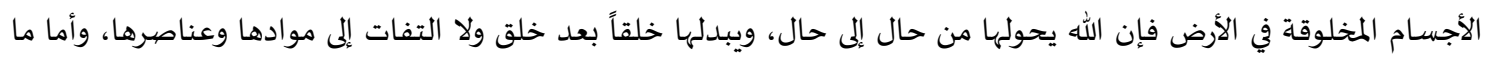

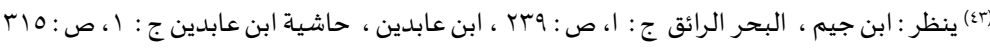

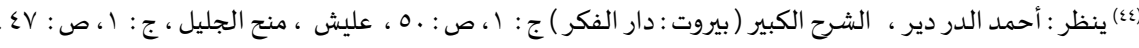
أ)

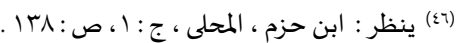

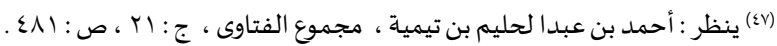

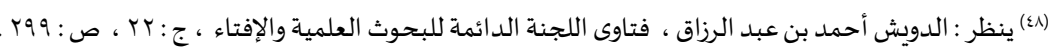

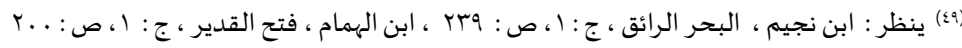
r

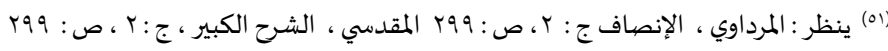

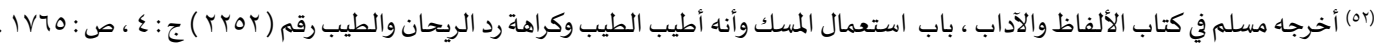

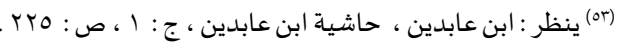

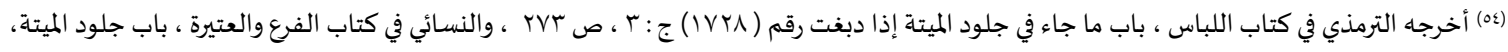

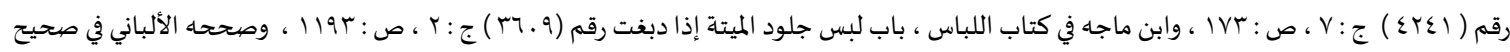

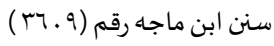

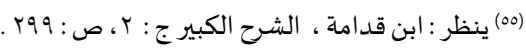

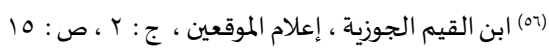


استحال بسبب كسب الإنسان كإحراق الروث حتى يصير رماداً ووضع الخنزير في الملاحة حتى يصير ملحاً، ففيه خلاف مشهور، وللقول بالتطهير اتجاه " (ov)

الدليل من المعقول:

أن الطهارة والنجاسـة متعلقة بحقائق الأعيان فإذا انتفت هذه الحقائق انتفى الحكم معها، ولأن استحالة الأعيان أعظم من

استحالة الخمر فاستحالها تطهر من باب أولى (ه). أدلة القول الثاني:

ا. عن عبدالله بن عمر رضي الله عنهما قال : نهى رسول الله -صلى الله عليه وسلم- عن أكل الجلالة وألبانها(09)

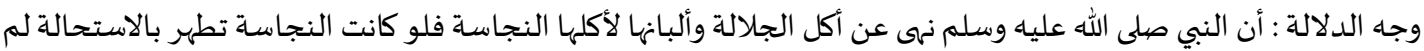

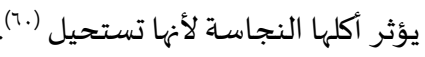

r. أنها نجاسـة لم تحصل بالاستحالة فلم تطهر بها كالدم إذا استحال لهال قيحاً وصديداً (17).

الترجيح:

القول الأول هو القول الراجح فمتى استحال النجس إلى مادة أخرى فإن هذه العين تكون طاهرة ولا معنى للحكم بنجاستها وهي

مادة أخرى، مادة لها نظير آخر لهم يبق للنجاسة اسم ولا معنى وهذا حيث زالت النجاسة تماماً فلم يبق لا لون ولا طعم ولا ريح.

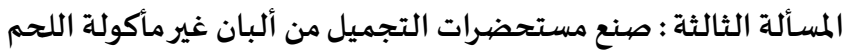

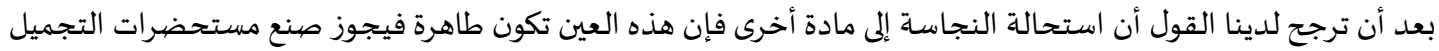

من ألبان غير مأكولة اللحم إذا تحولت إلى مادة أخرى، ومن ضمن قرارات " المنظمة الإسلامية للعلوم الطبية" - وقد بحثت موضيوع "

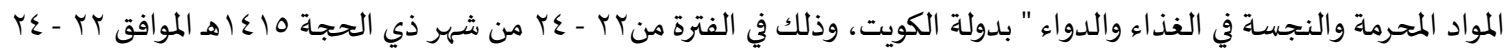

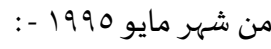

الاستحالة التي تعني انقلاب العين إلى عين أخرى تغايرها في صفاتها ، تحول المواد النجسة أو المتنجسة إلى مواد طاهرة، وتحول

المواد المحرمة إلى مواد مباحة شرعاً. . وبناء على ذلك:

الجيلاتين المتكون من استحالة عظم الحيوان النجس وجلده وأوتاره : طاهر وأكله حلال . الصابون الذي ينتج من استحالة شحم الخنزير أو الميتة يصير طاهرا بتلك الاستحالة ويجوز استعماله. الجبن المنعقد بفعل إنفحة ميتة الحيوان المأكول اللحم طاهر ويجوز تناوله. • المراهم والكريمات ومواد التجميل التي يدخل في تركيها شحم الخنزير لا يجوز استعمالها إلا إذا تحققت فيها استحالة الشحم

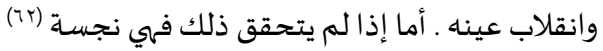

المبحث الثاني: التداوي بألبان البهائم، وفيه مطلبان: - المبان المطلب الأول: التداوي بألبان الإبل: لقد شرع الإسلام التداوي بكل طاهر مباح، فقد روى أبو داود من حديث أبي الدرداء رضي الله عنه أن النبي صلى الله عليه

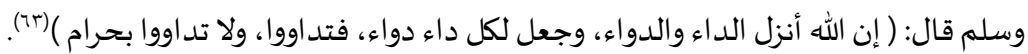

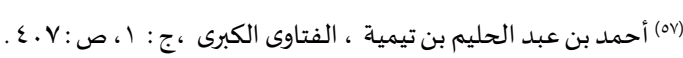

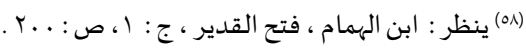

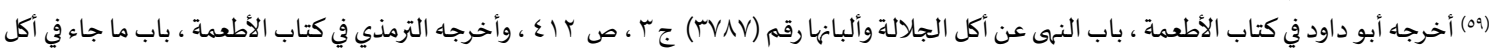

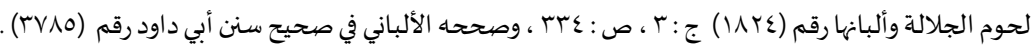

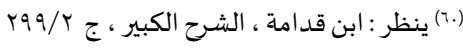

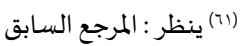

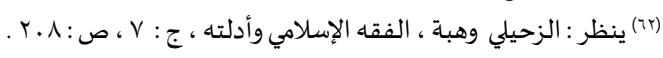

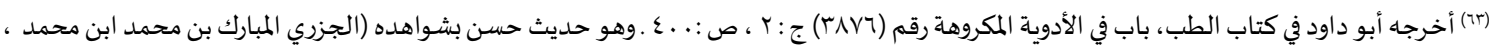

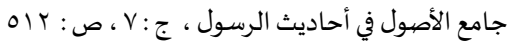


كما دلت السنة النبوية على جواز التداوي بألبان الإبل وأنه علاج لبعض الأمراض فقد جاء في الصحيحين من حديث أنس

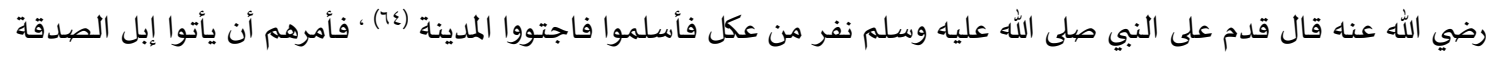

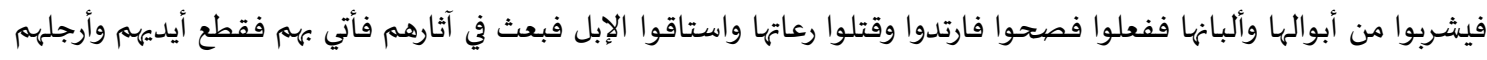
وسمل أعينهم ثم لم يحسمهم حتى ماتوا (10) .

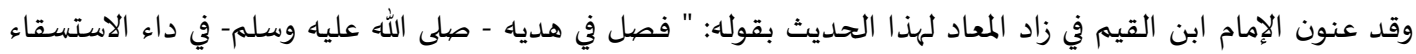

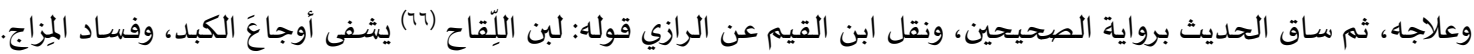

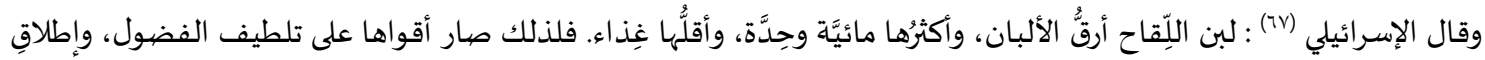

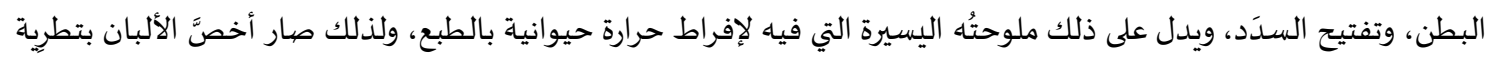

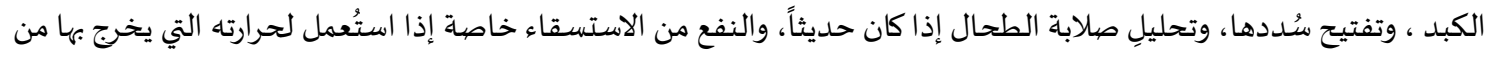

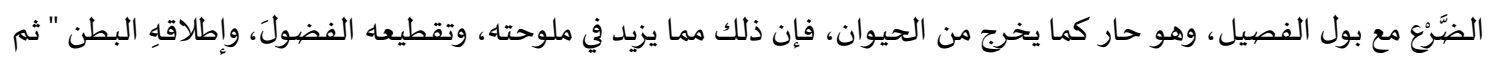

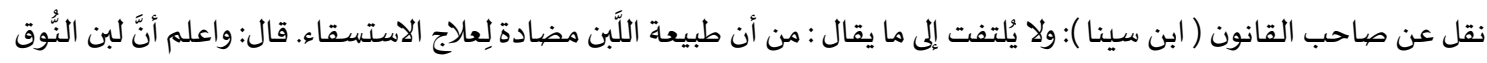

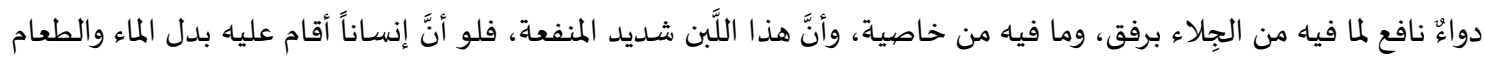

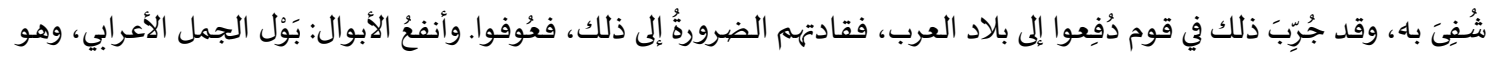
النجيب (11) ") (19) ) وفي مقال بجريدة الاتحاد تتناول دراسة الدكتور محمد مراد في مجال الطب والصحة إلى أنه في الماضي استخدم العرب حليب

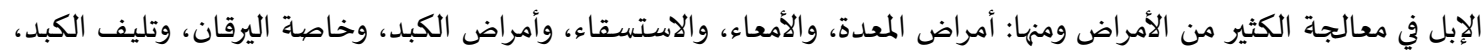

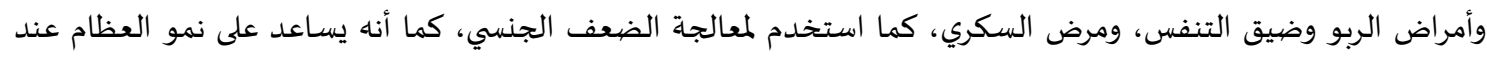

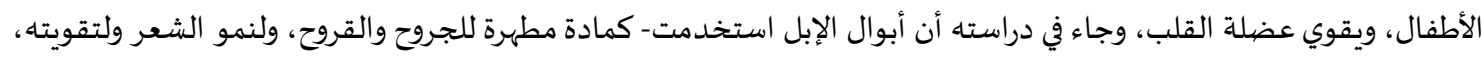

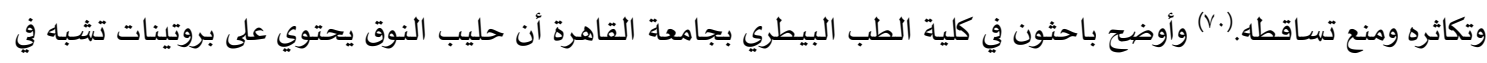

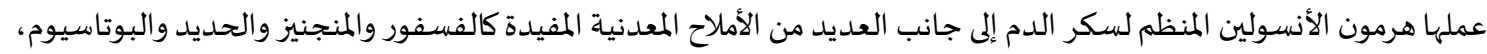

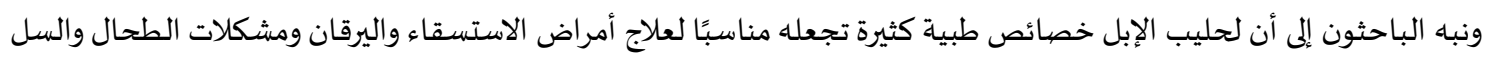

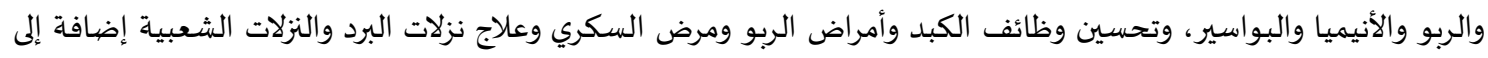

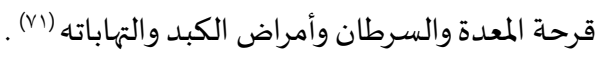

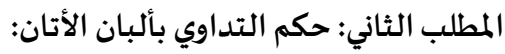

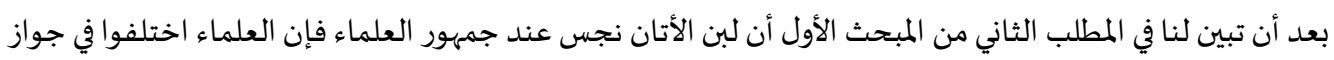

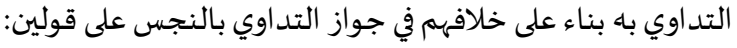
القول الأول: يحرم التداوي بألبان الأتان وهو قول أبي حنيفة وأبي يوسف من التئن الحنفية (Vr) ، وهو قول الحنابلة (Vrr).

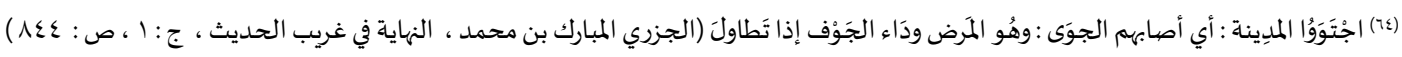

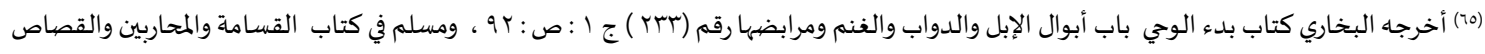

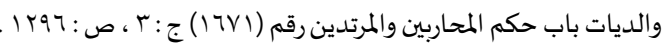

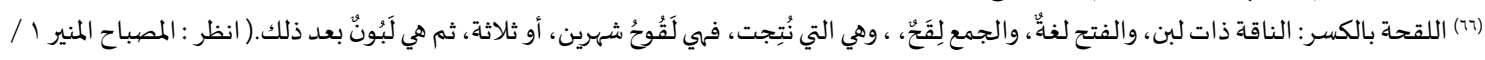

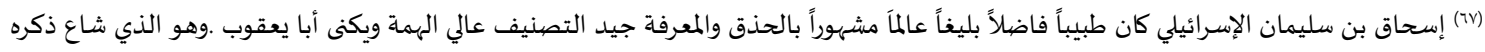

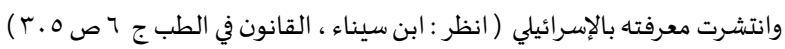

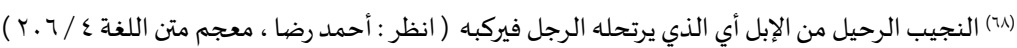

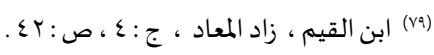

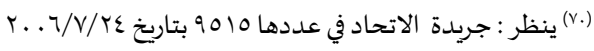
(1) مقال" الإعجاز العلمي في الطب النبوي: التداوي بألبان الإبل وأبوالها، لزكريا الحسيني محمد، نشر على موقع مداد الالكتروني http://midad.com/article/197827

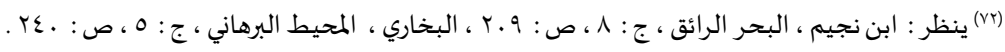

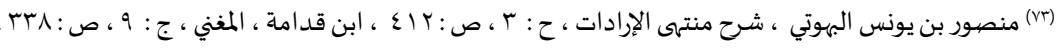


قال في مجمع الأنهر: " ولا يحل شرب لبن الأتان بالفتح هي أنثى الحمر الأهلية لكون اللبن متولدا من لحم" (Vع). قال ابن قدامة رحماه الله: " ولا يجوز التداوي بمحرم , ولا بشيء فياه محرم، مثل ألبان الأتن، جمع أتان وهي أنثى الحمار.، ولحم شيء

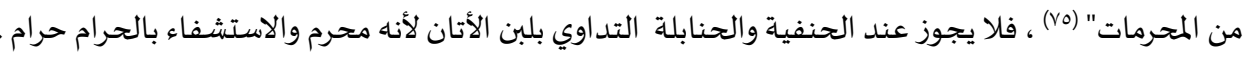

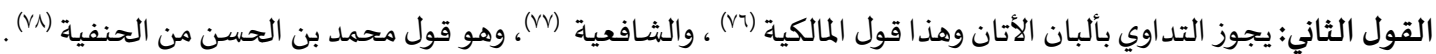

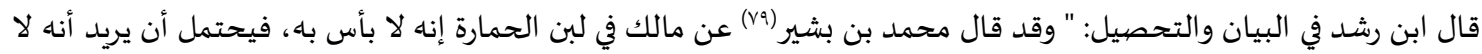

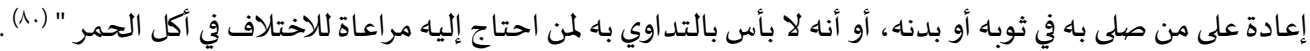

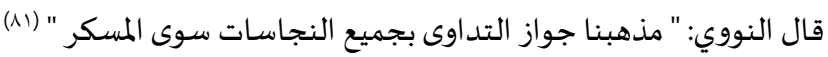

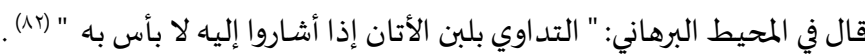
يظهر من هذا أن التداوي بألبان الأتان جائز عند المالكية مراعاة للخلاف في جواز أكلها، والشافعية بناء على قاعدتههم في جواز

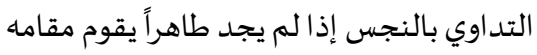

أدلة القول الأول:

الدليل الأول: عن أبى الدرداء رضي الله عنه قال : قال رسول الله صلى الله عليه وسلم : ( إن الله أنزل الداء والدواء وجعل لكل داء

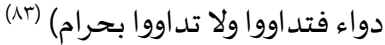

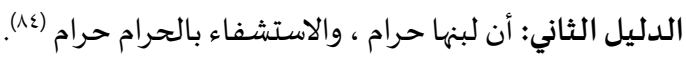

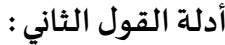

الدليل الأول: أن مصلحة العافية والسلامة أكمل من مصلحة اجتناب النجاسة (10)

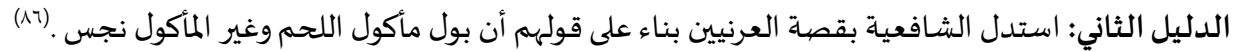

الترجيح:

الراجح القول الأول؛ لأن ألبان الحمير محرمة ولم يجعل الله تعالى شفاء عباده بما حرم عليهم، وما استدل باه الشافعية من أن الن النها

بول الإبل نجس وأمر النبي صلى الله عليه وسلم العرنيين بشربه للتداوي مع نجاستاه مردود بأن لبن الإبل طاهر وليس بنجس الئس لأن

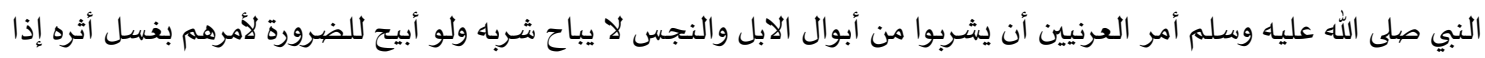
أرادوا الصلاة (Av)، ولا يصح أن يقال إنما أذن في شرب أبوال الإبل للتداوي لقول النبي صلى الله عليه وسلم: ( فتداووا ولا تداووا بحرام) وقول عبدالله بن مسعود رضي الله عنه في السكر : ( إن الله لم يجعل شفاءكم فيما حرم عليكم ) (^) .

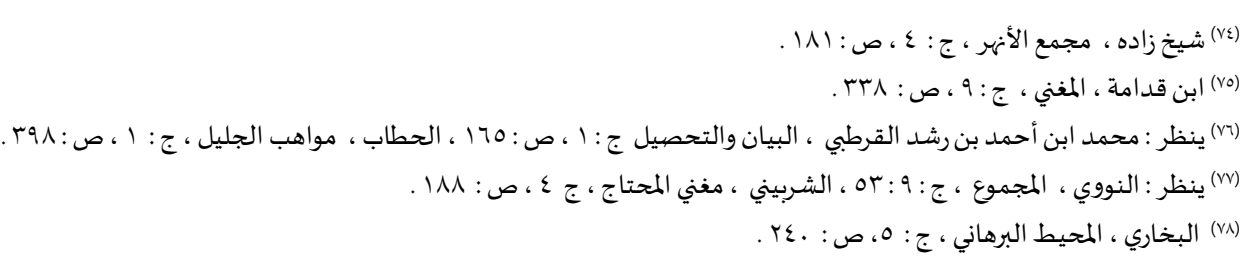

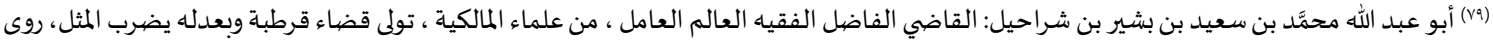
عن مالك وعنه جماعة، توفي سنة 191 هـ ( انظر : شجرة النور الزكية في طبقات المالكية / / ع ج )

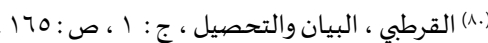

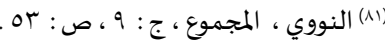

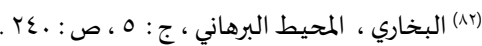

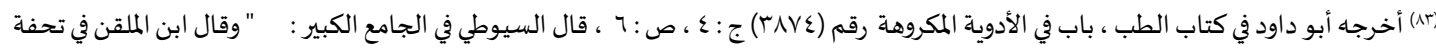

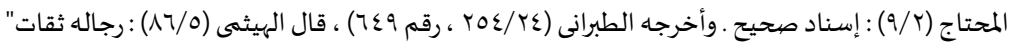
(^)

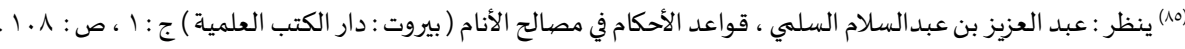

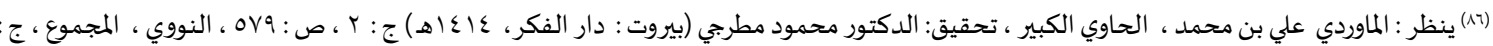

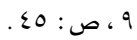

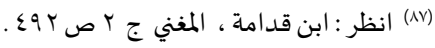

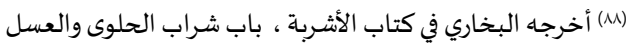


الخاتمـة:

الحمد لله وحده ، ولصلاة والسلام على من لا نبي بعده.... وبعد

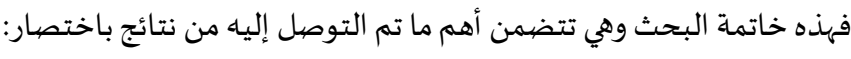
ا ـ إن دين الإسلام يحث على الجمال الذي لا تصحباه مخيلة . r ا إن الحليب من أهم المواد التي تدخل في تركيب مستحضرات التجميل وتنظيف البشرة ، وذلك لأن الحليب له أثر في تجديد الخلايا والتخفيف من حدة الالتهابات .

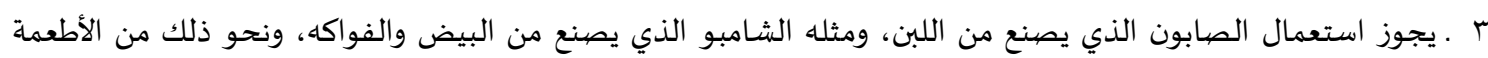

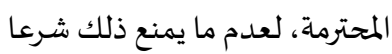

ع ـ يجوز استخدام المستحضرات التجميلية التي تصنع من ألبان الحيوانات مأكولة اللحم .

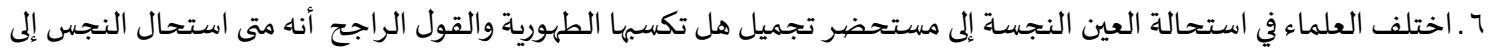

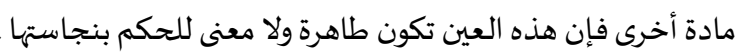

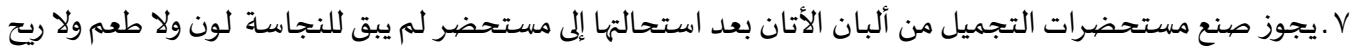

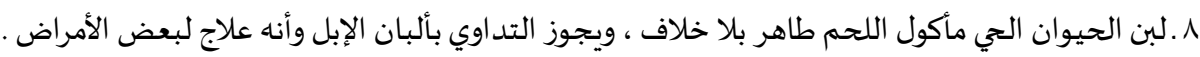

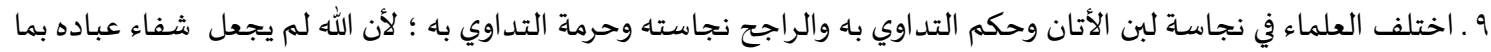
حرم عليهم.

التوصيية: بحث المنتجات الجديدة المستخلصة من بقية أجزاء الحيوانات غير اللبن.

المراجع:

1. ابن تيمية، أحمد بن عبد الحليم، (ب ت) الفتاوى الكبرى، مصر،، دار الكتب الحديثة.

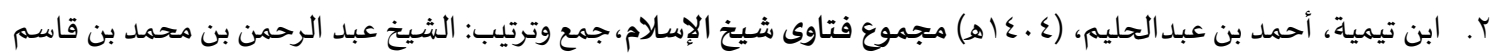
النجدي الحنبلي، القاهرة، مكتبة النهضية الحديثة .

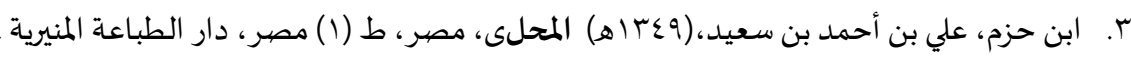

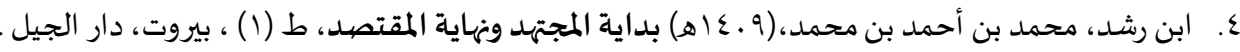

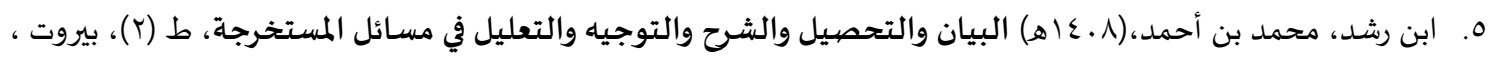
دار الغرب الإسلامي .

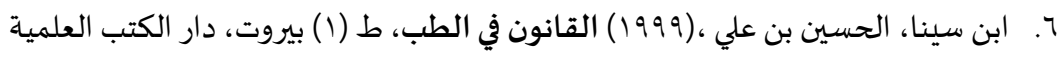

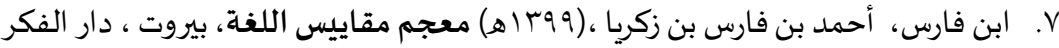

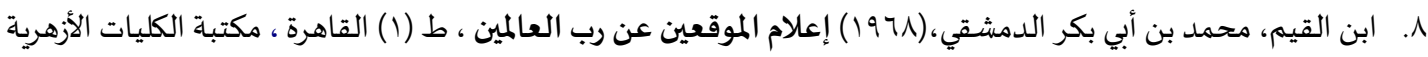

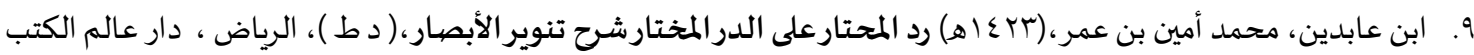

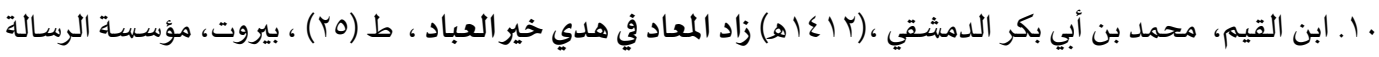

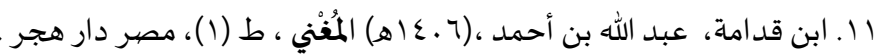

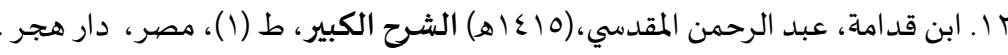

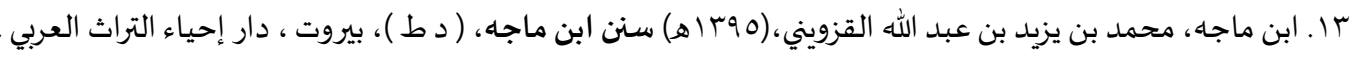

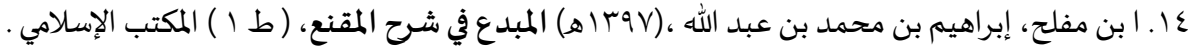

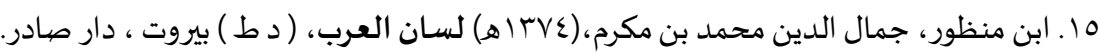

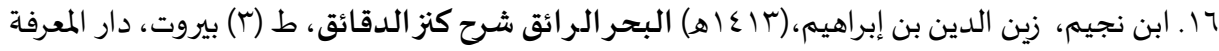

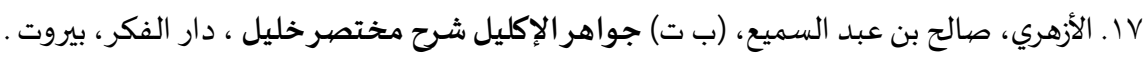

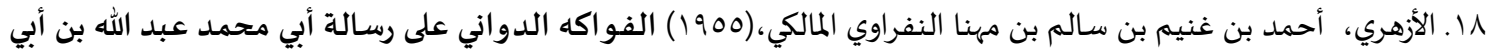

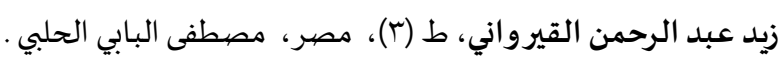


19 ـ الألباني ، محمد ناصر الدين ،99 (9) (ه) إرواء الغليل في تخريج أحاديث منار السبيل، ط (1) بيروت، المكتب الإسلامي .

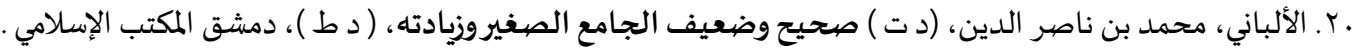

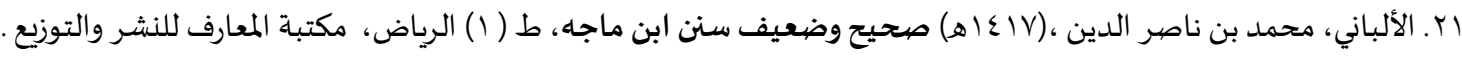

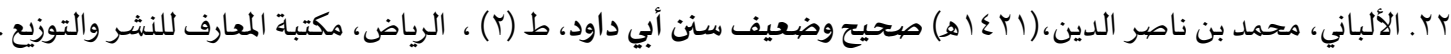

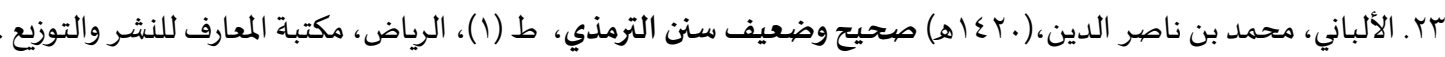

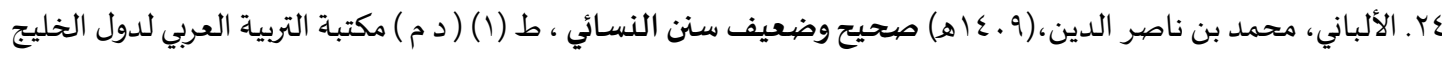

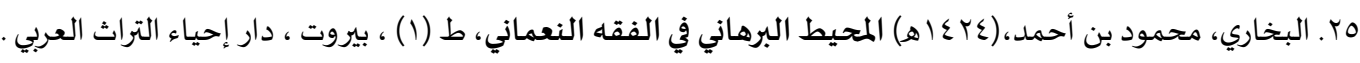

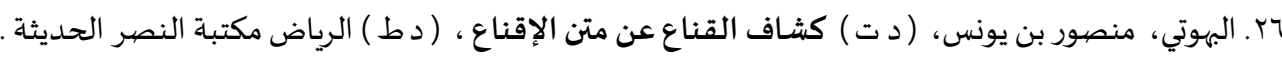

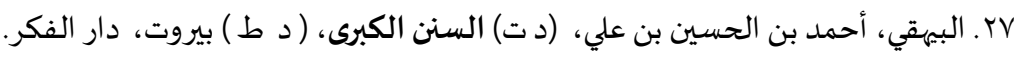

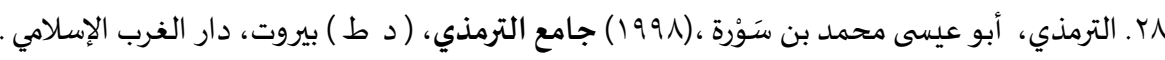

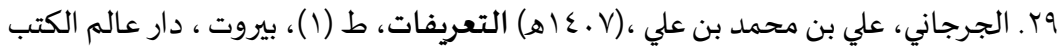

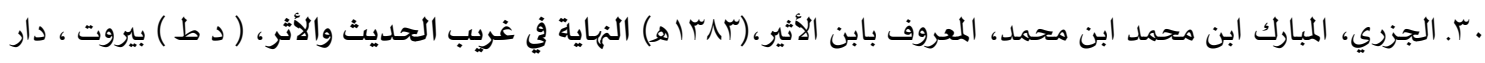

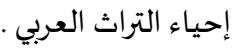

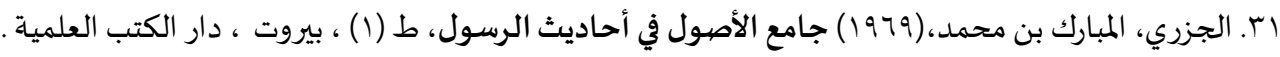

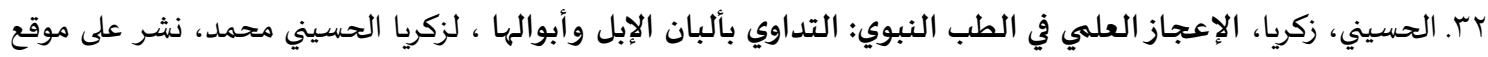

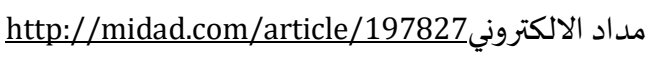

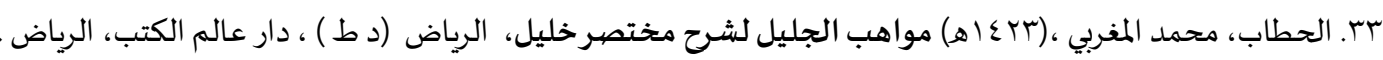

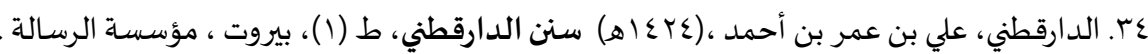

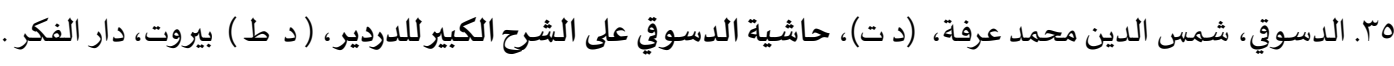
بr.

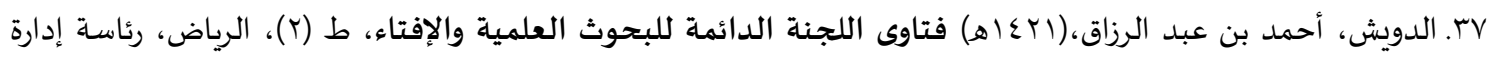
البحوث العلمية والإفتاء.

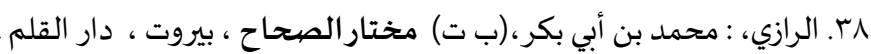

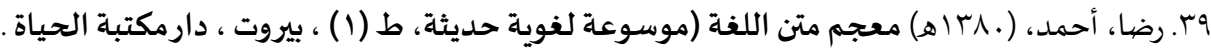

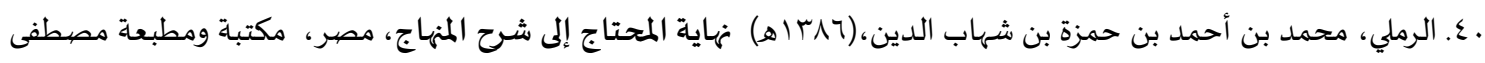
الحلبي.

اءع. الزحيلي، وهبة ، ( د ت ) الفقه الإسلامي وأدلته، (د ط ) دمشق ، دار الفكر .

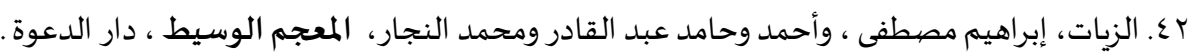
بع. الشربيني، شمس الدين محمد بن محمد الخطيب، (د ت) مغني المحتاج إلى معرفة معاني ألفاظ المنهاج، (د ط ) بيروت، دار دار الفكر.

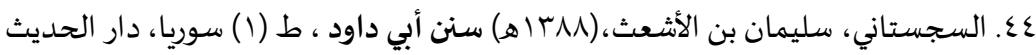

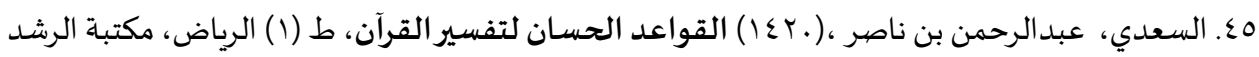

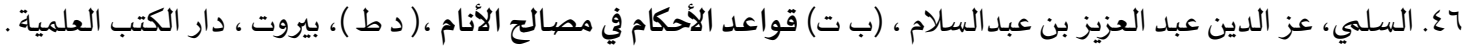

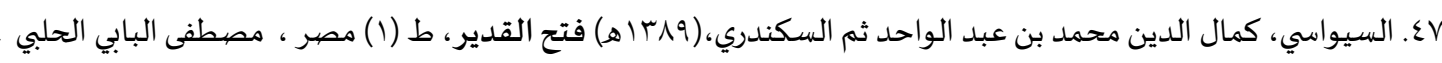

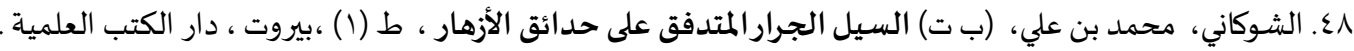

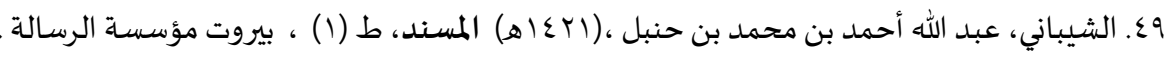
• 0.

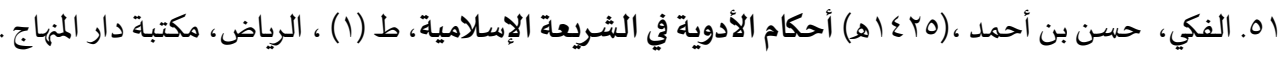

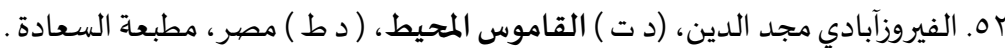
rه. الفيومي أحمد بن محمد بن علي المقري، ( د ت ) المصبباح المنير في غريب الشرح الكبير للرافعي، ( د ط ) بيروت ، المكتبة العلمية . 


$$
\text { عه. القرافي، أحمد بن إدريس،(1991) الذخيرة، ط (1) بيروت، دار الغرب الإسلامي، بيروت . }
$$

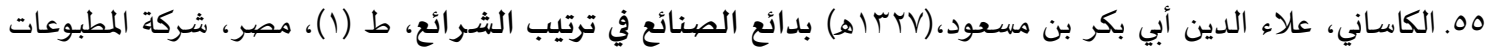

هo الكليبولي، عبد الرحمن بن محمد ، (1991) مجمع الأهرفي شرح ملتقى الأبحر ( د ط )، بيروت ، دار الكتب العلمية. .

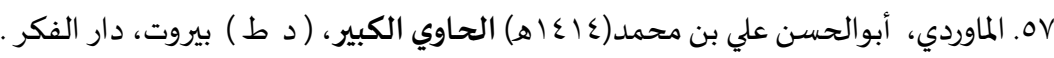

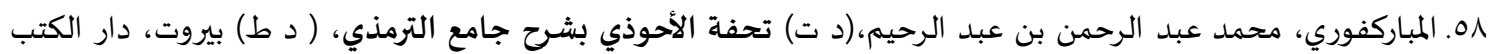

09. مخلوف، محمدل بن محمد، (T . . . شجرة النور الزكية في طبقات المالكية، ط (1) بيروت ، دار الكتب العلمية .

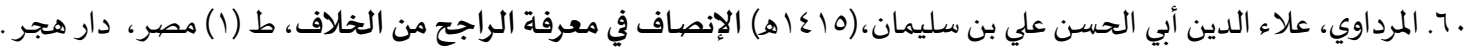

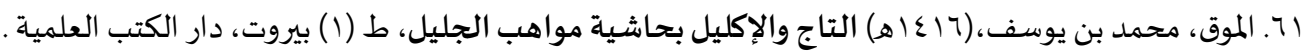

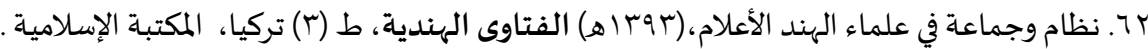
با7. النووي، محيبي الدين بن شرف، (د ت) المجموع شرح المهذب، (د ط ) الفجالة، المكتبة العالمية . ع7. النووي، يحيى بن شرف، (د ت) شرح صحيح مسلم، ( د ط )، الرياض، رئاسة إدارات البحوث العلمية والإفتاء والدعوة والإرشاد.

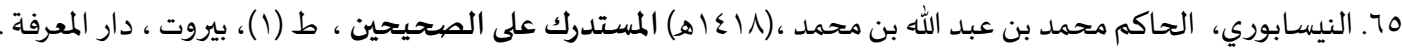
77. النيسابوري، مسلم بن الحجاج القشيري، ( د ت ) صحيح مسلم، (د ط )، استنبول، المكتبة الإسلامية.

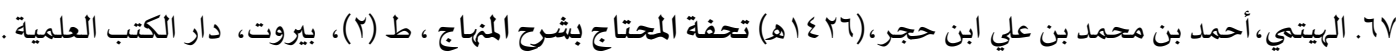

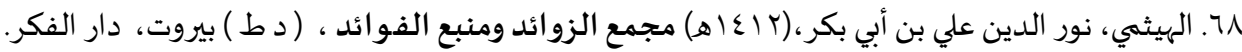

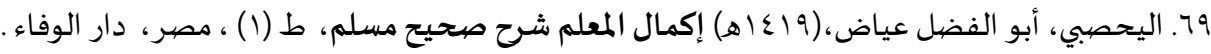


المجلة الدولية للدراسات الإسلامية المتخصصصة

International Journal of Specialized Islamic Studies (SIS)

www.refaad.com

Journal Homepage: https://www.refaad.com/views/SIS/Home.aspx ISSN: 2617-6246(Online) 2617-6238(Print)

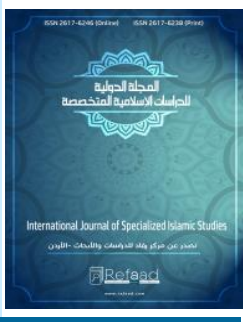

\title{
Cosmetics and Medicines from Beast Dairy (Jurisprudence Study)
}

\author{
Khalid bin Abdulrahman Al-Askar \\ Associate Professor, Faculty of Education, Prince Sattam Bin Abdulaziz University, KSA \\ Kalid1927@hotmail.com
}

DOI: https://doi.org/DOI:10.31559/sis2020.4.1.3

Abstract: Many cosmetic and skin care manufacturers have tended to include milk or milk in many of their products and make it an essential substance in the manufacture of many moisturizers, which called for research this issue from a legal point of view, which includes the statement of the purity of milk animals eating meat, the ruling on the use of these dairy in the manufacture of cosmetics, the statement of the impurities of milk animals meat, and the rule of using these milks in the manufacture of cosmetics, and the rule of medicine, and through research the manufacture of cosmetics from the animals whether it is meat or not eating meat and it is permissible to treat the animal's milk with meat, and it is not permissible to treat the animal's milk other than meat.

Keywords: Cosmetics; medicines; dairy; beasts.

\section{References:}

[1] Ạbn 'ạbdyn. Mḥmd Ạ̉myn Bn 'mr, Rd Ạlmḥtạr 'la Ạldr Ạlmkḥtạr Sh̆rḥ Tnwyr Ạlạ̉bșạr (D Ṭ), Ạlryạd, Dạr 'ạlm Ạlktb, (1423h)

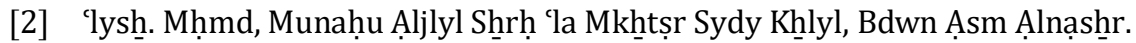

[3] Ạlạ̉lbạny. Mḥmd Nạșr Ạldyn, Árwạ’ Ạlghlyl Fy Tkhryj Ạ̉hạdytḥ Mnạr Ạlsbyl, (T1) Byrwt, Ạlmktb Aląslạmy, (1399h)

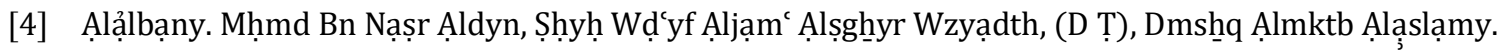

[5] Ạlạ̉lbạny. Mḥmd Bn Nạșr Ạldyn, Șḥyḥ Wḍ̣yf Snn Ạbn Mạjh, (T1) Ạlryạḍ, Mktbë Ạlm’ạrf Llnsḥr Wạltwzy', (1417h)

[6] Ạlạ̉lbạny. Mḥmd Bn Nạṣr Ạldyn, Ṣhyḥ̣ Wḍ̂yf Snn Ạ̉by Dạwd, (T2), Ạlryạḍ, Mktbë Ạlmª̣rf Llnsh̆r Wạltwzyc, (1421h)

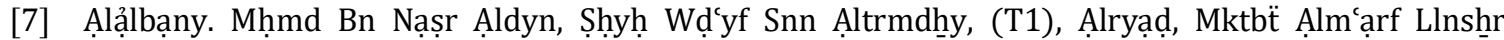
Wạltwzy', (1420h)

[8] Ạlạ̉lbạny. Mḥmd Bn Nạșr Ạldyn, Șhỵh Wọ̣cyf Snn Ạlnsậ̉y, (T1) (D M) Mktbë Ạltrbyh Ạl'rby Ldwl Alkhlyj, (1409h)

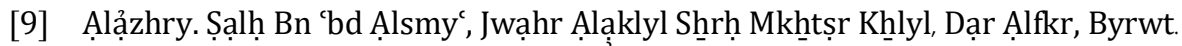

[10] Alạ̉zhry. Ảhmm Bn Ghnym Bn Sạlm Bn Mhnạ Alnfrạwy Almạlky, Alfwạkh Aldwạny la Rsạlẗ Ạ̉by Mḥmd 'bd Ạllh Bn Ạ̉by Zyd 'bd Ạlrḥmn Ạlqyrwạny, Ṭ (3), Mṣr, Mșțfa Ạlbạby Ạlḥlby, (1955)

[11] Ạlbkhạry. Mḥmwd Bn Ạ̉ḥmd, Ạlmḥyṭ Ạlbrhạny Fy Ạlfqh Ạln`mạny, (T1), Byrwt, Dạr Ạhyạ’ ẠltrạthAl'rby, (1424h)

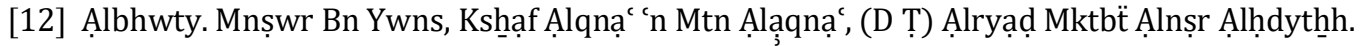

[13] Ạlbyhqy. Ạ̉hmo Bn Ạlḥsyn Bn 'ly, Ạlsnn Ạlkbry, (D Ṭ) Byrwt, Dạr Ạlfkr.

[14] Ạldạrqțny. 'ly Bn 'mr Bn Ạ̉ḥmd, Snn Ạldạrqțny, (T1), Byrwt, Mw̉ssë Ạlrsạlh, (1424h)

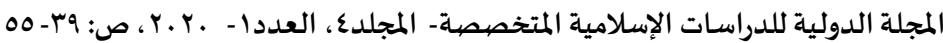


[15] Ạldswqy. Shms Ạldyn Mḥmd 'rfh, (DT), Ḥạsḩÿ̈ Ạldswqy 'la Ạlsḥrḥ Ạlkbyr Lldrdyr, (D Ṭ) Byrwt, Dạr Alfkr.

[16] Ạldwsry. Yạsr, Ạ̉ḥạm Mstḥ̣̣̂ạt, Mwq Yạsr Ạldwsry: https://www.aldosry.net/pageother-15.html

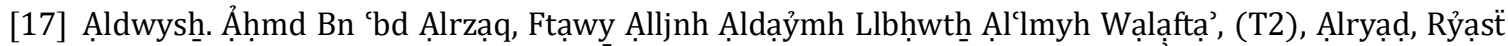

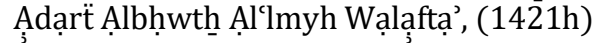

[18] Ạbn Fạrs. Ạ̉ḥmd Bn Fạrs Bn Zkryạ, M’jm Mqạyys Ạllgh̆hh, Byrwt, Dạr Ạlfkr, (1399h)

[19] Ạlfky, Ḥsn Bn Ạ̉ḥmd, Ạ̉ḥạm Ạlạ̉dwyh Fy Ạlshrych Ạlạslạmyh, (T1), Ạlryạd, Mktbë Dạr Ạlmnhạj, (1425h)

[20] Ạlfyrwzậbạdy Mjd Ạldyn, Ạlqạmws Ạlmḥyț, (D Ṭ) Mṣr, Mṭb ‘̈ Ạls’ạdh.

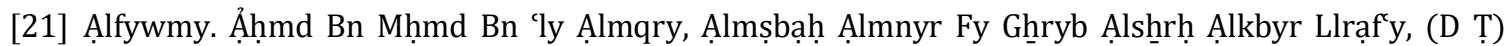
Byrwt, Ạlmktbh Ạl'lmyh.

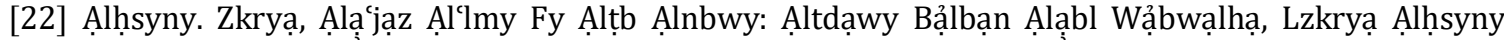

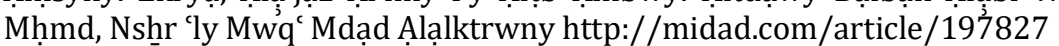

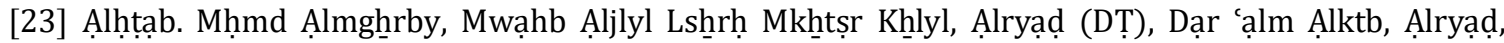
(1423h)

[24] Alhytmy. Ạhmmd Bn Mḥmd Bn Jy Ạbn Ḥjr, Tḥft Ạlmḥtạj Bshrhh Ạlmnhạj, (T2), Byrwt, Dạr Ạlktb Al'lmyh, (1426h)

[25] Ạlhythnmy, Nwr Ạldyn 'ly Bn Ạ̉by Bkr, Mjm Ạlzwậ̉d Wmnb` Ạlfwậd, (D Ṭ) Byrwt, Dạr Ạlfkr, (1412h)

[26] Ạbn Ḥzm. 'ly Bn Ạ̉ḥmd Bn S'yd, Ạlmḥly, Mṣr, (T1) Mṣr, Dạr Ạlțbạ ho Ạlmnyryh, (1349h)

[27] Ạljrjạny. 'ly Bn Mḥmd Bn 'ly, Ạlt'ryfạt, (T1), Byrwt, Dạr cạlm Ạlktb, (1407h)

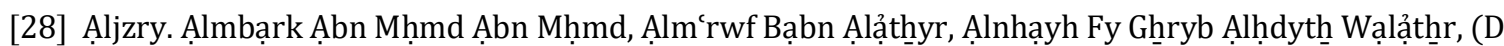
T) Byrwt, Dạr Ạhyạ’ Ạltrạth Ạl'rrby, (1383h)

[29] Ạljzry. Ạlmbạrk Bn Mḥmd, Jạm ‘ Ạlạ̉ṣwl Fy Ạ̉ḥạdyth Ạlrswl, (T1), Byrwt, Dạr Ạlktb Ạl'lmyh, (1969)

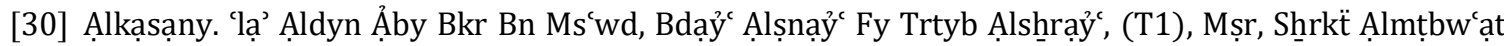
Al'lmyh, (1327h)

[31] Ạlklybwly. 'bd Ạlrḥmn Bn Mḥmd, Mjm Ạlạ̉nhr Fy Sh̆rḥ Mltqy Ạlạ̉bḥr (D Ṭ), Byrwt, Dạr Ạlktb Ạl'lmyh, (1998)

[32] Ạbn Mạjh. Mḥmd Bn Yzyd Bn 'bd Ạllh Ạlqzwyny, Snn Ạbn Mạjh, (D Ṭ), Byrwt, Dạr Ạhyạ’ ẠltrạthẠl'rby, (1395h)

[33] Ạlmạwrdy. Ạ̉bwạlḥsn 'ly Bn Mḥmd, Ạlḥạwy Ạlkbyr, (D Ṭ) Byrwt, Dạr Ạlfkr, (1414h)

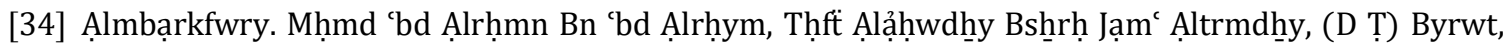
Dạr Ạlktb Ạl'lmyh.

[35] Ạ Bn Mflḥ. Ábrạhym Bn Mḥmd Bn 'bd Ạllh, Ạlmbd`Fy Sh̆ḥ̣ Ạlmqn', (Ṭ1) Ạlmktb Ạlạslạmy, (1397h)

[36] Ạbn Mnẓwr. Jmạl Ạldyn Mḥmd Bn Mkrm, Lsạn Ạl'rb, (D Ṭ) Byrwt, Dạr Ṣạdr, (1374h)

[37] Mkhllwf. Mḥmd Bn Mḥmd, Sḥjrë Ạlnwr Ạlzkyẗ Fy Ṭbqạt Ạlmạlkyh, (T1) Byrwt, Dạr Ạlktb Ạl'lmyh, (2003)

[38] Ạlmrdạwy. 'lạ’ Ạldyn Ạ̉by Ạlḥsn 'ly Bn Slymạn, Ạlạnșạf Fy M'rft Ạlrạjḥ Mn Ạlkhlạf, (T1) Mṣr, Dạr Hjr, (1415h)

[39] Ạlmwq. Mḥmd Bn Ywsf, Ạltạj Wạlạklyl Bḥạshyë Mwạhb Ạljlyl, (T1) Byrwt, Dạr Ạlktb Ạl'lmyh, (1416h)

[40] Ạbn Njym. Zyn Ạldyn Bn Ábrạhym, Ạlbḥr Ạlrậ̉q Sh̆rḥ Knz Ạldqậ̉q, (T3) Byrwt, Dạr Ạlmrfh, (1413h)

[41] Ạlnwwy. Mḥyy Ạldyn Bn Sh̆rf, Ạlmjmw` Sh̆rḥ Ạlmhdhhb, (D Ṭ) Ạlfjạlh, Ạlmktbh Ạl'ạlmyh.

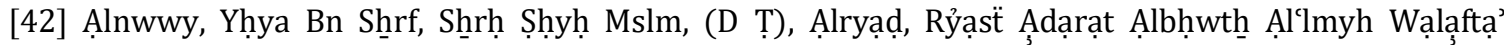
Wạld'wh Wạlạrshạad.

[43] Ạlnysạbwry, Ạlḥạm Mḥmd Bn 'bd Ạllh Bn Mḥmd, Ạlmstdrk ly Ạlșḥyhyn, (T1), Byrwt, Dạr Ạlmrfh, (1418h) 
[44] Ạlnysạbwry, Mslm Bn Ạlḥjạj Ạlqshyyry, Șhỵh Mslm, (D Ṭ), Ạstnbwl, Ạlmktbh Ạląslạmyh.

[45] Nzạm Wjmạch Fy 'lmạ’ Ạlhnd Ạlặ lạm, Ạlftạwy Ạlhndyh, (T3) Trkyạ, Ạlmktbh Ạlạjslạmyh, (1393h)

[46] Ạbn Qdạmh ,bd Ạllh Bn Ạ̉ḥmd, Ạlmughinny, Ṭ (1), Mṣr Dạr Hjr, (1406h)

[47] Ạbn Qdạmh. 'bd Ạlrḥmn Ạlmqdsy, Ạlsh̆rḥ Ạlkbyr, Ṭ (1), Mṣr, Dạr Hjr, (1415h)

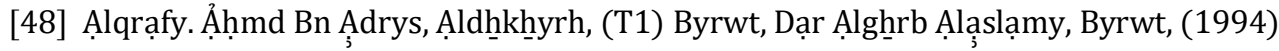

[49] Ạbn Ạlqym. Mḥmd Bn Ạ̉by Bkr Ạldmshnqy, A̧ lạm Ạlmwq'yn 'n Rb Ạl'ạlmyn, (T1) Ạlqạhrh, Mktbë Ạlklyạt Ạlạ̉zhryh, (1968)

[50] Ạbn Ạlqym. Mḥmd Bn Ạ̉by Bkr Ạldmsḥqy, Zạd Ạlmª̣d Fy Hdy Khyr Ạl'bạd, (T25), Byrwt, Mw̉ssï Ạlrsạlh, (1412h)

[51] Ạlrạzy, Mḥmd Bn Ạ̉by Bkr, Mkḥtạr Ạlș̣hạh, Byrwt, Dạr Ạlqlm, (B T)

[52] Rḍạ. Ạ̉hmmd, M`jm Mtn Ạllghhh (Mwsw'h Lghwyh Ḥdythhh, (T1), Byrwt, Dạr Mktbë ạlhyạh, (1380h)

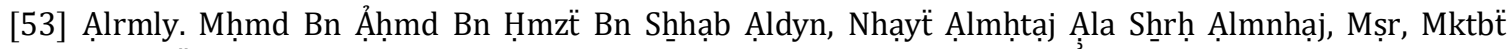
Wmțbđ̈ Mștfa Ạlḷlby, (1386h)

[54] Ạbn Rsh̆d. Mḥmd Bn Ạ̉hmmd Bn Mḥmd, Bdạyẗ Ạlmjthd Wnhạyẗ Ạlmqtṣd, (T1), Byrwt, Dạr Ạljyl, (1409h)

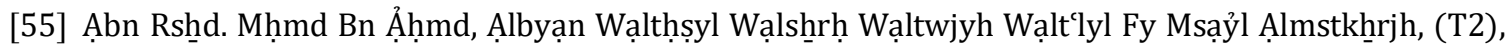
Byrwt,Dạr Ạlghrb Ạląislạmy, (1408h)

[56] Ạls`dy. 'bdạlrḥmn Bn Nạssr, Ạlqwạadd Ạlḥsạn Ltfsyr Ạlqrận, (T1) Ạlryạd, Mktbë Ạlrsh̄d, (1420)

[57] Ạlshhrbyny, Shms Ạldyn Mḥmd Bn Mḥmd Ạlkḥtyb, Mghnny Ạlmḥtạj Ȧla M'rft M‘ạny Ạ̉lfạz Ạlmnhạj, (D T) Byrwt, ạr Âlfkr.

[58] Ạlshwwkạny, Mḥmd Bn ly, Ạlsyl Ạljrạr Ạlmtdfq la Ḥdạyq Ạlạ̉zhạr, (T1), Byrwt, Dạr Ạlktb Ạl'lmyh.

[59] Ạlshybạny. 'bd Ạllh Ạ̉hmmd Bn Mḥmd Bn Ḥnbl, Ạlmsnd, (T1), Byrwt Mw̉ssë Ạlrsạlh, (1421h)

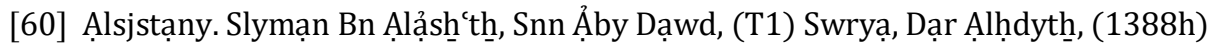

[61] Ạlslmy. 'z Ạldyn ‘bd Ạl'zyz Bn 'bdạlslạm, Qwậd Ạlạ̉hkạm Fy Mṣalḥ Ạlạ̉nạm, (DṬ), Byrwt, Dạr Ạlktb Ạl'Imyh.

[62] Ạbn Synạ. Ạlḥsyn Bn Iy, Ạlqạnwn Fy Ạlț̣, (T1) Byrwt, Dạr Ạlktb Ạl'lmyh, (1999)

[63] Ạlsywạsy. Kmạl Ạldyn Mḥmd Bn 'bd Ạlwạhd Tḥm Ạlskndry, Ftḥ Ạlqdyr, (T1) Mșr, Mșța Ạlbạby Ạlhlby, (1389h)

[64] Ạltrmdhyy, Ạ̉bw ysa Mḥmd Bn Saẘrh, Jạmª̣ltrmdhny, (D Ṭ) Byrwt, Dạr Ạlghhrb Ạlạslạmy, (1998)

[65] Ạbn Tymyh. Ạ̉hmm Bn 'bd Ạlḥlym, Ạlftạwy Ạlkbrỵ, Mṣr, Dạr Ạlktb Ạlḥdythַh.

[66] Ạn Tymyh. Ạ̉hmd Bn 'bdạlhlym, Mjmw' Ftạwy Shykh Alaslạm,Jm Wtrtyb: Ạlsȟykh 'bd Ạlrḥmn Bn Mḥmd Bn Qạsm Ạlnjdy Ạlḥnbly, Ạlqạhrh, Mktbë Ạlnhḍh Ạlḥ̉dythhh, (1404h)

[67] Ạlyḥṣby. Ạ̉bw Ạlfụl 'yạd, Ảkmạl Ạlm Im Sḥrḥ Șḥyḥ Mslm, (T1), Mṣr, Dạr Ạlwfạ’', (1419h)

[68] Ạlzḥyly. Whbh, Ạlfqh Ạlạslạmy Wạ̉dlth, (D Ṭ) Dmsh̄q, Dạr Ạlfkr.

[69] Ạlzyạt. Ạbrạhym Mșṭa, Wạ̉hmo Whạmd 'bd Ạlqạdr Wmḥmd Ạlnjạr, Ạlm'jm Ạlwsyț, Dạr Ạld'wh. 